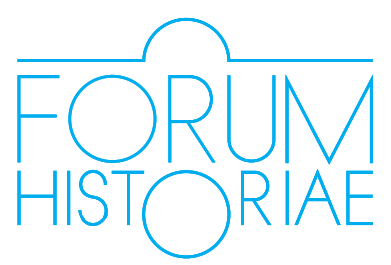

\title{
Věrnost v Kosmově kronice
}

\author{
Jakub Razim
}

\begin{abstract}
RAZIM, Jakub: Fidelity in the Chronicle of the Czechs by Cosmas of Prague.

This study focuses on the Chronica Boemorum by Cosmas of Prague, which is one of the most important narrative sources for Czech history in the era of the Přemyslid dynasty. An analysis of this literary work attempts to address the question of how the chronicler worked with the category of fidelity that is nowadays considered to be one of the fundamental ideas and widespread legal forms through which the medieval society expressed its hierarchical order. It is no coincidence that domestic rulers and noble persons closely related to the throne found themselves at the centre of attention, as most of the information that Prague dean Cosmas left behind is related to members of the political elite. Following the pioneering monograph of Dušan Třeštík, the concept of fidelity in the Chronica Boemorum is discussed and reinterpreted. The main reason is that Třeštík's approach is based on traditional fief terminology and doctrine, which has been recently attacked by postmodern deconstructivists headed by prominent British historian Susan Reynolds. At first, legal rituals, such as promises and oaths, are presented as means to establish, strengthen, or terminate fidelity ties, binding together Přemyslids and provincial magnates. The major part of the study is then devoted to the content of fidelity commitments. Although it was based predominantly on the duty of loyalty and service, medieval fides or fidelitas was not at all uniform. On the contrary, it flexibly adapted to the socio-cultural and geographical context. Therefore, it seems appropriate to examine this topic with the help of an analytical probe that captures the (un)loyal rulers and their servants depicted in the Chronica Boemorum as heroes providing encouragement to be followed, or villains worthy of condemnation. While doing so, a methodological inspiration may be drawn from the classical work of František Graus and, under his influence, it is possible to distinguish one-sided uncompromising obedience (obedientia) from two-sided fidelity based on reciprocity (fides, fidelitas).
\end{abstract}

Keywords: Middle Ages, Přemyslids, monarchy, Czech Lands, Kosmas, Chronica Boemorum (Kosmas's chronicle), fidelity, oaths of fidelity

DOI: https://doi.org/10.31577/forhist.2019.13.2.2

\section{Kníže a jeho věrní}

$\mathrm{V}^{2}$ příspěvku se budu zabývat Kosmovou kronikou, proslulým literárním dílem z 12. století, jež skýtá bohatství informací o českých dějinách za vlády Přemyslovců. Je tedy jen přirozené, začít citátem z pera Dušana Třeštíka, medievisty, který je považován za předního znalce tohoto kronikářského díla. ${ }^{1} \mathrm{~V}$ Třeštíkově vlivné monografii s názvem Kosmova kronika a s podtitulem Studie $k$ počátkům českého dějepisectví a politického myšlení se můžeme dočíst následující řádky: „Kníže je pro Kosmu především pánem, jediným pánem všech Čechů, kteří jsou jeho vasaly. Je možné, že termíny, kterých jsme tu nuceni používat, nevystihují plně specifiku českých lenních vztahů té doby, nesporné ovšem je, že lenní právo analogické tomu, které známe z jiných zemí, tehdy v Čechách existovalo." Nebo o stránku dále:

1 Komentovanou bibliografii sestavil KOPAL, Petr. Král versus kníže? Idea panovnické moci v Kosmově kronice. In WIHODA, Martin - REITINGER, Lukáš (eds.) Proměna středovýchodní Evropy raného a vrcholného středověku. Mocenské souvislosti a paralely (dále Proměna středovýchodní Evropy). Brno : Matice moravská, 2010, s. 359-371, zde s. 368-371. 
„Vše, co u Kosmy skutečně jasně vystupuje, se soustřed'uje okolo vyhraněné ideologie věrnosti, která se právě v 11. století silně rozvíjí."

Třeštík rekonstruuje sociální a myšlenkovou tvářnost přemyslovské epochy pod vlivem svého učitele a nadřízeného v Historickém ústavu ČSAV Františka Grause. ${ }^{3}$ Spolu s Grausem předpokládá, že se u nás za časů kronikáře a pražského děkana Kosmy etablovala lenní pyramida. Obyvatelstvo bylo spojeno předivem osobní a majetkové závislosti (formální hledisko), půda byla v Čechách a na Moravě rozdělována do dočasného užívání výměnou za poskytnutí služeb (materiální hledisko). Kdo ve spleti feudálně-vazalských práv a povinností uvízl, musel si být vědom morálního př́ikazu věrnosti neboli fidelity, třebaže se jím vždycky a ve všem neřídil. Organizační platforma spolupráce mezi přemyslovským seniorem na knížecím stolci a jeho českými vazaly se údajně vyvíjela z domácích kořenů, avšak nelišila se od situace, jaká byla v zemích středověké západní Evropy. Tak lze v kostce charakterizovat Grausem navržený a Třeštíkem převzatý model přemyslovského „státu“ doby knížecí. ${ }^{4}$ Nelze sice říci, že by odborná veřejnost zůstala netečná k otázkám, které si v 60. letech 20. století položil Dušan Třeštík. ${ }^{5}$ Pravdou ale je, že o srovnatelnou analýzu věrnosti v soukolí mocenského dualismu českého knížete a velmožů se po Třeštíkovi už nikdo nepokusil, ačkoliv máme pádné důvody se domnívat, že diskuze je stále otevřená. ${ }^{6}$

Impulsem k opětovnému promýšlení „státnosti“ v době Kosmově může být třeba kritika hlásaná britskou historičkou Susan Reynoldsovou, která rozvírila polemiku ve vědeckých kruzích svým konstatováním, že feudálně-vazalský systém se v Evropě nezačal rozvíjet dříve než ve 12 . století a že byl výtvorem učených právníků ve službách byrokratizující se monarchie. Reynoldsové kniha Fiefs and vassals otřásla tradiční naukou lenního státu a práva, ukotvenou v právněhistorických učebnicích a příručkách, přičemž dozvuky jejího tažení proti „mýtu feudalismu“ se nevyhnuly

2 TŘEŠTÍK, Dušan. Kosmova kronika. Studie k počátkům českého dějepisectví a politického myšlení. Praha ; Brno : Academia, 1968, citáty na s. 161, 162. Své výsledky přetavil taktéž do populárněji laděné knihy TŘEŠTÍK, Dušan. Kosmas. 2. vyd. Praha ; Brno : Melantrich, 1972 a zde zvl. s. 187 a násl.

3 Srv. VÁLKA, Josef - WIHODA, Martin. Mysliti (na) Dušana Třeštíka. In Časopis Matice moravské, 2007, roč. 126, č. 2, s. 254-262.

4 GRAUS, František. Lenní právo v Čechách. In Český lid, 1952, roč. 7, č. 3-4, s. 67-73. 0 „feudální ideologii věrnosti“ GRAUS, František. Počátky českého státu a vývoj „státní“ ideologie. In Slavia Occidentalis, 1962, roč. 22, s. 147-163, s. 150 a násl. K lennímu diskursu v českém dějepisectví ZELENKA, Jan. Beneficium et feudum. Podoba a proměny lenního institutu. Praha : Historický ústav, 2016, s. 114 a násl.; NOVOTNÁ, Markéta. Uchopení lenní problematiky v české a evropské literatuře z hlediska historiografického diskursu. In Historia Slavorum Occidentis, 2014, roč. 2(7), s. 199-211, zde s. 204 a násl.

5 Stručně RUSSOCKI, Stanisław. Elita władzy w Kronice Ćzechów Kosmasa Praskiego. In Pamiętnik Słowiański, 1973, roč. 23, s. 237-255, zde s. 253-254; BLÁHOVÁ, Marie. Stát a vláda státu v pojetí kronikáře Kosmy. In PANIC, Idzi - ISPERKA, Jerzy (eds.) Średnowiecze polskie i powszechne 2. Katowice : Wydawnictwo Uniwersytetu Śląskiego, 2002, s. 115-137, zde s. 135-136; KOPAL, Petr. „Politické hry“ v Kosmově kronice. In DOBOSZ, Józef - KUJAWIŃSKI, Jakub - MATŁA-KOZŁOWSKA, Marzena (eds.) Pierwsze polsko-czeskie forum młodych mediewistów. Poznań : Instytut Historii UAM, 2007, s. 89-121, zvl. s. 95, 104-105.

6 Samotný autor se k problému vrátil už jen v drobných poznámkách MERHAUTOVÁ, Anežka - TŘEŠTíK, Dušan. Ideové proudy v českém umění 12. století. Praha : Academia, 1985, s. 19-20; TŘEŠTíK, Dušan. „Gloria regni“ Vratislava II. Hymnus „Versus post missam“ a kronikář Kosmas. In NODL, Martin - SOMMER, Petr - DOLEŽALOVÁ, Eva (eds.) Verba in imaginibus. Františku Šmahelovi k 70. narozeninám. Praha : Argo, 2004 s. 285-298, zde s. 287, 294; TŘEŠTíK, Dušan. Počátky českého politického myšlení. In HEROLD, Vilém MÜLLER, Ivan - HAVLÍČEK, Aleš (eds.) Dějiny politického myšlení II/1. Politické myšlení raného křest'anství a středověku. Praha : OIKOYMENH, 2011, s. 404-446, zde s. 427. 
ani českému prostředí. ${ }^{7} \mathrm{~K}$ přehodnocení starších názorů nabádá ale i ta část historiografie, jež dokáže lépe než kdysi docenit různé odstíny fidelity a postihnout celou škálu jejího uplatnění v mezilidských vztazích. Pokud nahlédneme do sborníků bilancujících výzkum z poslední doby, naznáme, že fenoménu věrnosti se podařilo úspěšně vymanit nejen ze zajetí „germánských“, ale nyní už i „feudálně-vazalských" interpretačních schémat. ${ }^{8}$ Historická věda postupuje v těsném sepětí s př́ibuznými humanitními obory a poukazuje na proměnlivost objektu našeho zájmu, at’ už v čase, nebo v závislosti na konkrétních životních okolnostech. ${ }^{9}$ Věrnost je prezentována jednak jako etická hodnota, jednak jako pravidlo chování, jehož hlavní náplní byla ve středověku loajalita a ochota sloužit. ${ }^{10}$ Tvrdí se také, že fidelita usnadňuje bezkonfliktní fungování společnosti a zvyšuje její soudržnost. Často opakovaným argumentem proto je, že uvádí do pohybu mechanismus reciprocity, který sbližuje jednotlivce a redukuje nejistotu v běžné komunikaci. Vzbuzuje totiž v člověku očekávání, posilované všemožnými symbolickými praktikami, že se může v budoucnu na druhého obrátit a že se dočká solidární pomoci. ${ }^{11}$

Jak patrno, oproti Třeštíkovi máme výhodu, že se ve svých úvahách o věrnosti můžeme opřít o rozsáhlejší metodologické zázemí, které je obohaceno o interdisciplinární přístupy a tříbeno na neustále se množících pramenných studiích. Jestliže se čím dál naléhavěji zdůrazňuje, že fidelita odedávna patřila k pilírum společenského řádu a že nebyla žádným historickým monolitem, je legitimní tázat se, jakou podobu na sebe brala u nás v období Přemyslovců. Vzhledem k tematickému záběru tohoto časopiseckého čísla je nasnadě, že se v centru pozornosti ocitnou knížata a velmoži. Jsou koneckonců čelními protagonisty Kosmovy kroniky, která je nenahraditelným zdrojem poučení o minulosti. Až na výjimky bude tak odhlédnuto od náboženské sféry, v níž křest’ané vystupují jakožto fideles Dei. Všímat si důsledně nebudu ani přeshraničních styků s otonsko-sálskou říší a piastovským Polskem, jejichž barvité peripetie by vydaly na samostatnou publikaci. Startovním bodem se stane terminologická sonda do Kosmova slovníku, kde lze mezi cca 90 výskyty latinských výrazů fides a fidelitas včetně jejich opozit

7 REYNOLDS, Susan. Fiefs and vassals. The medieval evidence reinterpreted. Oxford : OUP, 1994. K tomu ZELENKA 2016, s. 154 a násl.

8 Výběrově FAŁKOWSKI, Wojciech - SASSIER, Yves (eds.) Confiance, bonne foi, fidélité. La notion de fides dans la vie des sociétés médiévales (VIe-XVe siècles) (dále Confiance, bonne foi, fidélité). Paris : Classiques Garnier, 2018; SONNTAG, Jörg - ZERMATTEN, Coralie (eds.) Loyalty in the Middle Ages. Ideal and practice of a cross-social value (dále Loyalty in the Middle Ages). Turnhout : Brepols, 2016; LEPSIUS, Susanne - REICHLIN, Susanne (eds.) Fides / Triuwe (dále Fides / Triuwe). Berlin : Akademie-Verlag, 2015. Na jednotlivé studie v těchto sbornících obsažené bude ještě odkazováno potud, pokud se jeví relevantní.

9 Ve světle formulí přísah ESDERS, Stefan. Fidelität und Rechtsvielfalt. Die sicut-Klausel der früh- und hochmittelalterlichen Eidformulare. In BOUGARD, François (ed.) Hiérarchie et stratification sociale dans l'Occident médiéval (400 - 1100). Turnhout : Brepols, 2008, s. 239-256. Ze starších publikací napřs. BECHER, Matthias. Eid und Herrschaft. Untersuchungen zum Herrscherethos Karls des Großen. Sigmaringen : Thorbecke, 1993; MAGNOU-NORTIER, Elisabeth. Fidélité et féodalité méridionales d'après les serments de fidélité (Xe - début XIIe siècle). In Annales du midi, 1968, roč. 80, č. 89, s. 457-484. U nás se o vytěžení př́ísah a slibů z úředních písemností 13. století zasloužil JAN, Libor. Lenní př́ísahy a přísahy věrnosti na dvoře posledních Přemyslovců. In WIHODA, Martin - MALATÁK, Demeter (eds.) Stát, státnost a rituály premyslovského věku. Problémy, názory, otázky. Brno : Matice moravská, 2006, s. 101-112.

10 ESDERS 2008, s. 254.

11 Ve zhuštěné podobě REHBERG, Karl-Siegbert. Reziprozität und institutionelle Risikoverminderung. Soziologische Anmerkungen zur „Loyalität“ In Loyalty in the Middle Ages, s. 423-452. Na vybraném př́kladu GÖRICH, Knut. Fides und fidelitas im Kontext der staufischen Herrschaftspraxis (12. Jahrhundert). In Fides / Triuwe, s. 294-309. 
podchytit tři významové roviny: důvěru, (křest’anskou) víru a věrnost. ${ }^{12}$ Těžiště práce bude následně spočívat v praxeologickém rozboru oněch případů, které se točily okolo věrnosti. Cílem bude představit dějinné aktéry a odhalit logiku jejich jednání. ${ }^{13}$ Nemusí jít nutně jen o sociální kontext, ale zároveň o intenzitu, s jakou se fidelita prosazovala, klidně i v kolizi s jinými normami. ${ }^{14}$

\section{Rituály věrnosti}

Než přistoupím k detailnějšímu záběru na Kosmovo pojetí fidelity, zastavím se v krátkosti u právních rituálů, kterými se navazovala, posilovala, či zpřetrhávala věrnostní pouta sbližující vladaře $\mathrm{z}$ dynastie Přemyslovců s velmožskou elitou. ${ }^{15}$ V Kronice Čechů se setkáváme s obraty data fide, per fidei sponsionem a fidem promissam, za kterými lze rozeznat věrnostní sliby pronášené v okamžicích, kdy vyvstala potřeba stabilizovat přemyslovské knížecí panství dovnitř a navenek. ${ }^{16}$ Závazek loajality byl veřejně artikulován při uzavírání mírových smluv a vojenských aliancí se sousedními Piastovci, ${ }^{17}$ anebo, což je pro sledovanou problematiku závažnější, když si panovník chtěl pojistit oddanost mužů rozsazených v hradských centrech, z nichž byly přemyslovské země spravovány. ${ }^{18}$ Sliby působily jako sociální tmel, at' je kníže od svých lidí vynucoval, nebo je sám dával. Názornou ukázkou může být „volební agitace“ moravského údělníka Svatopluka, který se chystal roku 1104, že připraví o knížecí úřad Bořivoje II. Aniž by se pouštěl do zbrklého útoku na Prahu, Svatopluk raději vsadil na tajné shánění přívrženců po Čechách. Moravští poslové dostali proto za úkol, nešetřit úplatky, dary ani sliby, aby k sobě přivábili nespokojence s Bořivojovým režimem (alios pecunia corrumpunt, alios muneribus, alios promissionibus obligant). ${ }^{19}$ Téhož prostředku ostatně užil pět let nato i Boři-

12 Obecně WEIJERS, Olga. Some notes on „fides“ and related words in medieval Latin. In Archivum latinitatis medii aevi, 1977, roč. 40, s. 77-102; HELBIG, Herbert. Fideles Dei et regis. Zur Bedeutungsentwicklung von Glaube und Treue im hohen Mittelalter. In Archiv für Kulturgeschichte, 1951, roč. 33, č. 1, s. 275-306; KROESCHELL, Karl. Die Treue in der deutschen Rechtsgeschichte. In KROESCHELL, Karl. Studien zum frühen und mittelalterlichen deutschen Recht. Berlin : Duncker \& Humblot, 1995, s. 157-182; SCHULTZ-BALLUFF, Simone. Triuwe - Verwendungsweisen und semantischer Gehalt im Mittelhochdeutschen. In KRIEGER, Gerhard (ed.) Verwandtschaft, Freundschaft, Bruderschaft. Soziale Lebens- und Kommunikationsformen im Mittelalter. Berlin : Akademie Verlag, 2009, s. 271-296.

13 LEPSIUS, Susanne - REICHLIN, Susanne. Einleitung. In Fides / Triuwe, s. 221-230. K tomu KELLER, Hagen. Zum Charakter der „Staatlichkeit“ zwischen karolingischer Reichsreform und hochmittelalterlichem Herrschaftsausbau. In Frühmittelalterliche Studien, 1989, roč. 23, č. 1, s. 248-264, zvl. s. 255 a násl.

14 DEUTINGER, Roman. Königsherrschaft im Ostfränkischen Reich. Eine pragmatische Verfassungsgeschichte der späten Karolingerzeit. Ostfildern : Thorbecke, 2006, s. 102-103.

$15 \mathrm{~K}$ pojmovému ukotvení elit(y) v historiografii středověku GOETZ, Hans-Werner. Eliten in der Forschung und im zeitgenössischen [Selbst-] Verständnis des frühen Mittelalters. In BOUGARD, François - GOETZ, Hans-Werner (eds.) Théorie et pratiques des élites au Haut Moyen Âge. Conception, perception et réalisation sociale. Turnhout: Brepols, 2011, s. 101-126. Pro naše země KALHOUS, David. Čeští velmoži 10. věku. In Sborník prací Filozofické fakulty brněnské univerzity. Řada historická (C), 2006, roč. 52, č. 1, s. 5-13.

160 jejich místě ve „veřejném“ prostoru WIHODA, Martin. Obtížné příbuzenství. Konflikty a smiřování přemyslovských knížat. In NODL, Martin - WIHODA, Martin (eds.) Rituál smírení. Konflikt a jeho řešení ve středověku. Brno : Matice moravská - Výzkumné středisko pro dějiny střední Evropy: prameny, země, kultura, 2008, s. 71-83, kde se ale směšují př́ísahy a sliby.

17 COSMAE, Lib. I, Cap. 34, s. 61; Lib. III, Cap. 1, s. 162; Lib. III, Cap. 16, s. 179. Edice: Cosmae Pragensis Chronica Boemorum. In MGH: Scriptores rerum Germanicarum. Nova series 2. BRETHOLZ, Bertold (ed.). Berolini : Weidmanos, 1923.

18 COSMAE, Lib. III, Cap. 32, s. 203. Srv. JAN, Libor. Budování monarchie českých Přemyslovců. Postřehy a úvahy. In Proměna středovýchodní Evropy, s. 117-136, zde s. 131, jenž už před časem vyzdvihl fakt, že se věrnostní poměr uvnitř vládnoucí elity realizoval prostřednictvím správy hradů.

19 COSMAE, Lib. III, Cap. 17, s. 180. 
voj, když se střetl o trůn s knížetem Vladislavem I., ale s jedním rozdílem, že si sliby a přísahy vymohl od svých podporovatelů, aby zvýšil jejich odhodlání změřit síly $\mathrm{s}$ Vladislavem (obligat sacramentis et promissionibus) ${ }^{20}$

Torzovitost pramenů bohužel zabraňuje lépe popsat rituální scénář a zjistit, jak probíhal a jak zněl přednes slibujícího. Nechybějí ale indicie, že ústně sdělené ujištění o věrnosti bylo doprovázeno symbolickým gestem, pakliže stanuli tváří v tvář vazal a jeho pán. Vodítkem je nám Kosmova relace o lenní svrchovanosti Břetislava II. nad polským knížetem Zbyhněvem. Dějepiscovo mnohoznačné per manus traditionem ${ }^{21}$ může odpovídat bud' podání, nebo vložení ruky do dlaní seniora, při kterémžto úkonu bývala ruka atributem moci, přenášené z jedné osoby na druhou. ${ }^{22}$ Bylo by však ošemetné, vyvozovat z tohoto úryvku, že celá přemyslovská monarchie nesla rysy feudálního uspořádání, jak tvrdil Dušan Třeštík. Hovoří-li kronikář o Češích a Přemyslovcích, nikde ani nenaznačuje, že by věrnostní imperativ byl nějak provázán s udělováním výsostných úřadů, práv či majetků směrem od knížete k předákům. Příhoda, která svedla dohromady Břetislava a Zbyhněva, nemůže být proto záminkou ke kombinaci, že by se na domácí půdě rozvinul klasický lenní systém pozůstávající ze dvou prvků, materiálního (léno) a personálního (fidelita), které by spolu měly být existenčně spjaty. ${ }^{23}$ Jistotu ohledně vnějškových projevů věrnosti tudíž postrádáme, zato máme spolehlivě zaznamenán jiný ve středověku rozšířený zvyk, že sliby byly zesilovány přísahami. ${ }^{24}$

Latinskými výrazy sacramentum, nebo výjimečně iuramentum se Kosmas dovolává přísah, o kterých italský historik Paolo Prodi se znalostí věci prohlásil, že v předmoderní Evropě tvořily základní výstavbový prvek, na němž byl vybudován

20 COSMAE, Lib. III, Cap. 29, s. 198.

21 Gesta rukou analyzují GARNIER, François. Le langage de l'image au Moyen Âge 1. Signification et symbolique. Paris : Le Léopard d'Or, 1995, s. 206 a násl.; BURROW, John Anthony. Gestures and looks in medieval narrative. Cambridge : CUP, 2002, s. 11 a násl.; PEIL, Dietmar. Die Gebärde bei Chrétien, Hartmann und Wolfram. Erec, Iwein, Parzival. München : W. Fink, 1975, s. 195 a násl., 198 a násl. Z právně-historické perspektivy VON AMIRA, Karl. Die Handgebärden in den Bilderhandschriften des Sachsenspiegels. In Abhandlungen. Bayerische Akademie der Wissenschaften. Phil.-hist. Klasse, 1909, roč. 23, s. 61-264, zde s. 239 a násl., 242 a násl. včetně latinské terminologie; VON AMIRA, Karl - VON SCHWERIN, Claudius. Rechtsarchäologie. Gegenstände, Formen und Symbole germanischen Rechts. Berlin ; Dahlem : Ahnerbe-Stiftung, 1943, s. 81, 83. Transcendentní rozměr probírají SCHMITT, Jean-Claude. Svět středověkých gest. Praha : Vyšehrad, 2004, s. 70 a násl.; LE GOFF, Jacques. Symbolický rituál vazalství. In LE GOFF, Jacques. Za jiný středověk. Praha : Argo, 2005, s. 335-402, zvl. s. 339-340, 348-349.

22 COSMAE, Lib. III, Cap. 1, s. 162. Různé interpretace tohoto poněkud enigmatického aktu najdeme u polských historiků: BENYSKIEWICZ, Krzysztof. Układ pokojowy Władysława Hermana z Brzetysławem II w 1093(94) roku w świetle Kroniki Kosmasa. In Śtudia nad Historiq, Kulturq i Polityka, 2008, roč. 2, s. 15-26; SOCHACKI, Jarosław. Polsko-czeski konflikt o Śląsk w ostatnim dziesięcioleciu XI w. In Gdańskie studia z dziejów średniowiecza, 2003, roč. 9, s. 255-271; LABUDA, Gerard. Kiedy książę Bolesław Krzywousty stał się lennikiem księcia czeskiego w ziemi kłodzkiej? (Przyczynek do krytyki Kroniki Czechów Kosmasa). In Annales Universitatis Mariae Curie-Skłodowska. Historia, 1990, roč. 45, s. 91-97.

23 Za všechny ALTHOFF, Gerd. Establishing Bonds. Fiefs, Homage, and Other Means to Create Trust. In BAGGE, Sverre - GELTING, Michael H. - LINDKVIST, Thomas (eds.) Feudalism. New Landscapes of Debate. Turnhout : Brepols, 2011, s. 101-114. Diferencovaněji KIENAST, Walther. Rechtsnatur und Anwendung der Mannschaft „Homagium“ in Deutschland während des Mittelalters. In WOLFF, Ernst (ed.) Deutsche Landesreferate zum 4. Internationalen Kongreß für Rechtsvergleichung in Paris 1954. Düsseldorf : Michael Triltsch, 1955, s. 26-48.

24 SCHMIDT-WIEGAND, Ruth. Eid und Gelöbnis, Formel und Formular im mittelalterlichen Recht. In CLASSEN, Peter (ed.) Recht und Schrift im Mittelalter. Sigmaringen : Thorbecke, 1977, s. 55-90, zde s. 57 a násl. Pro specifický vývoj na Rusi STEFANOVIČ, Petr S. Expressing Loyalty in medieval Russia. Oath vs. Oral Formulas. In AUZÉPY, Marie-France - SAINT-GUILLAIN Guillaume (eds.) Oralité et lien social au Moyen âge, Occident, Byzance, Islam : parole donnée, foi jurée, serment (dále). Paris : ACHCByz, 2008, s. 147-156. 
politický a právní řád. ${ }^{25}$ Ve stejném duchu se dnes píše o věrnostních přísahách, ${ }^{26}$ o nichž nacházíme doklady $v$ Kronice Čechů. Věříme-li svědectví pražského kronikáře, musíme dojít k závěru, že sacramenta byla v přemyslovské epoše praktikována i ve vnitřních, i v zahraničních vztazích a že nabývala formy bud' individuální, nebo kolektivní. Jejich posláním bylo garantovat do budoucna neporušenost panovníkovy vůle a pro tento účel mobilizovat jeho stoupence (tzv. promisorní přísahy). Jindy bylo považováno za nezbytné, aby př́ísahy dodaly váhu nějakému skutkovému tvrzení, at' se odehrálo na soudě či mimo něj (tzv. asertorní přísahy). ${ }^{27}$

Námětem přísah byly na jedné straně parametry soužití s okolními panovníky, nejen s piastovskými knížaty Boleslavem Chrabrým ${ }^{28}$ a Vladislavem Heřmanem, ${ }^{29}$ ale rovněž s římským králem Jindřichem V. Roku 1107 se totiž přemyslovský kníže Svatopluk, vězněný v saském Goslaru, musel přísežně zavázat, že výměnou za propuštění na svobodu a uznání trůnních práv vyplatí Jindřichovi deset tisíc hřiven stř́ibra. ${ }^{30} \mathrm{Na}$ straně druhé, pro nás pozoruhodnější, objevují se v politickém životě středověkých Čech a Moravy význačné události, během nichž obyvatelé přísahají, že budou stát loajálně při svém vladaři. Je nicméně typické, že Kosmas odhaluje pouze vrchol společenského ledovce, na jehož špičce je usazen pražský kníže. Kolektivně byla složena přísaha roku 1039 v průběhu vojenského tažení, které pod velením Břetislava I. proniklo do polského Hnězdna. Velmoži shromáždění nad hrobem svatého Vojtěcha $v$ cíli výpravy slavnostně přislíbili, že se budou do budoucna držet zákonů vtělených do tzv. hnězdenských dekret. ${ }^{31}$ Někdy za Břetislavova panování se pak museli přední z lidu zaručit svou věrností, že se postarají, aby byl po pražskému biskupovi Šebíri zvolen za jeho nástupce Břetislavův syn Jaromír. ${ }^{32}$ Když se konečně roku 1055 sešli členové knížecího doprovodu u lůžka, v němž na hradě v Chrudimi dožíval své dny již několikrát

25 PRODI, Paolo. Das Sakrament der Herrschaft. Der politische Eid in der Verfassungsgeschichte des Okzidents. Berlin : Duncker \& Humblot, 1997, passim a zvl. s. 63, 74 a násl., 83 a násl., 129. Dále srv. HOLENSTEIN, André. Die Huldigung der Untertanen Rechtskultur und Herrschaftsordnung (800 - 1800). Stuttgart ; New York : Gustav Fischer Verlag, 1991, se shrnutím na s. 507 a násl.; MICHAUD-QUANTIN, Pierre. Universitas. Expressions du mouvement communautaire dans le Moyen-Age latin. Paris : J. Vrin, 1970, s. 233 a násl. O fenoménu př́isah v Uhrách ZUPKA, Dušan. Rituály a symbolická komunikácia v stredovekej strednej Európe (Arpádovské Uhorsko 1000 - 1301). Prešov : Vydavatel'stvo Michala Vaška, 2011, s. 56-58.

26 Z novějších titulů ESDERS, Stefan. Rechtliche Grundlagen frühmittelalterlicher Staatlichkeit: der allgemeine Treueid. In POHL, Walter - WIESER, Veronika (eds.) Der frühmittelalterliche Staat. Europäische Perspektiven. Wien : ÖAW, 2009, s. 423-434; DEPREUX, Philippe. Les Carolingiens et le serment. In Oralité et lien social au Moyen âge, s. 63-80, zvl. s. 68 a násl.; FAŁKOWSKI, Wojciech. Les réactions sociales dans le cadre des serments de fidélité. In Confiance, bonne foi, fidélité, s. 209-224. Přehledově KOLMER, Lothar. Promissorische Eide im Mittelalter. Kallmünz : Lassleben, 1989, zvl. s. 76-77, 106, 354-356.

27 Shrnutí ŽEMLIČKA, Josef. Sacramenta v politickém životě přemyslovských Čech. In BŘEZINA, Luděk - KONVIČNÁ, Jana - ZDYCHINEC, Jan (eds.) Ve znamení zemí Koruny české. Sborník k šedesátým narozeninám prof. PhDr. Lenky Bobkové, CSc. Praha : Casablanca, 2006, s. 16-26; ŽEMLIČKA, Josef. Rituál přísahy a koruna Václava II. K obrazu dvora posledních Přemyslovců. In BOBKOVÁ, Lenka - HOLÁ, Mlada (eds.) Lesk královského majestátu ve středověku. Pocta prof. PhDr. Františku Kavkovi, CSc. k nedožitým 85. narozeninám. Praha ; Litomyšl : Paseka, 2005, s. 35-46; NODL, Martin. Sacramenta fidei. In DOLEŽEL, Jiří - WIHODA, Martin (eds.) Mezi raným a vrcholným středověkem. Pavlu Kouřilovi k šedesátým narozeninám přátelé, kolegové a žáci. Brno : Archeologický ústav Akademie věd České republiky, 2012, s. 433-441.

28 COSMAE, Lib. I, Cap. 34, s. 61.

29 COSMAE, Lib. III, Cap. 1, s. 162.

30 COSMAE, Lib. III, Cap. 21, s. 187.

31 COSMAE, Lib. II, Cap. 4, s. 86.

32 COSMAE, Lib. II, Cap. 22, s. 114; Lib. II, Cap. 23, s. 116. 
vzpomínaný „český Achilles“, zapřísáhli se umírajícímu Břetislavovi, že budou respektovat seniorát a $\mathrm{s}$ ním i přednost v nástupnictví pro nejstaršího z rodu Přemyslovců. ${ }^{33}$

Věrnost ale přísahali také urození jednotlivci, předstupující před knížete a zavazující sebe sama gesty a promluvami. Zpraveni jsme přinejmenším o jistém nejmenovaném bojovníkovi, který roku 1108 zasáhl do bojů o moc mezi českými knížaty, sesazeným a v polském exilu prodlévajícím Bořivojem II. a jeho přemožitelem Svatoplukem. Zatímco Bořivoj vpadl do východních Čech, opíraje se o piastovskou ozbrojenou pomoc, Svatopluk se zrovna podílel na řŕšské intervenci do Uher. Obrana země byla svěřena zemskému předákovi Vackovi, jenž byl zatlačen do defenzivy a v obtížné situaci se rozhodl uchýlit k vojenské lsti. Jednomu se svých mužů přikázal, aby se vydával za přeběhlíka a vetřel se tak do nepřátelského ležení. Tady Vackův bojovník křivě odpřisáhl na svou víru (confirmat per sue fidei sacramentum), že se Svatopluk vrací do vlasti, čímž přiměl Bořivoje s jeho piastovskými spojenci, aby se stáhli. „Lživými zprávami oni jsouce přestrašeni, téže noci se vrátili do Polska“, komentuje náš kronikář se zadostiučiněním, jak Vacek „převezl“ nenáviděné Poláky, vměšující se do cizích záležitostí a těžící z rozbrojů mezi Přemyslovci. Možná trochu zarážející může být shovívavý postoj k znevažování př́ísahy. Zapříčiněn je ale nepochybně česko-polskou animositou, která rezonuje u Kosmy natolik silně, že dovede ospravedlnit dokonce i perfidii Vackova špeha $\mathrm{v}$ táboře oblehatelů. ${ }^{34}$

Snadno bychom se mohli přesvědčit, že Kronika Čechů se zmiňuje právě tak často o fidelitě jako o jejím porušování, které se na první pohled zdá být běžným koloritem raně a vrcholně středověké vládní praxe. ${ }^{35} \mathrm{~A}$ přeci nelze $\mathrm{z}$ Kosmových příběhů o křivopřísežnících jednoduše usuzovat, že by věrnostní př́ísahy a sliby hrály ve „veřejném“ životě marginální roli, nebo že by neměly právní relevanci. ${ }^{36}$ Těžko by se potom vysvětlovalo, proč česká knížata vůbec lpěla na rituálech věrnosti. Ani by nebylo jasné, proč se kronikáři o tématiku zajímali a obšírně se o ní rozepisovali, odsuzujíce vesměs zradu a chválíce věrnost, navíc v souvislostech, které „hýbaly“ přemyslovským světem. Správnější bude souhlasit s míněním, podloženým Kosmovou výpovědí, že slíbená, nebo odpřisáhnutá věrnost byla jak nosnou

33 COSMAE, Lib. II, Cap. 13, s. 102.

34 COSMAE, Lib. III, Cap. 22, s. 189. O Kosmových stereotypech a invektivách vůči Polákům KRZEMIEŃSKA, Barbara. Polska i Polacy w opinii czeskiego kronikarza Kosmasa. In Zeszyty Naukowe Uniwersytetu Łódzkiego. Seria 1. Nauki Humanistyczno-Społeczne, 1960, roč. 15, s. 75-95; KRZEMIEŃSKA, Barbara. Češi a Poláci v mínění svých nejstarších kronikářù. In GROBELNÝ, Andělín - BAKALA, Jaroslav (eds.) Tisíc let česko-polské vzájemnosti 1, Opava : SIÚ ČSAV, 1966, s. 53-83; VANÍČEK, Vratislav. „Bohemi, infestissimi Polonorum inimi$c i^{\prime \prime}$ ? Literární emoce a politické reality od Galla Anonyma po Jindřicha z Isernie. In ODRZYWOLSKA-KIDAWA, Anna (ed.) Klio viae et invia. Opuscula Marco Cetwiński dedicata. Warszawa : DiG, 2010, s. 27-62.

$35 \mathrm{~K}$ porušování př́ísah a jeho významu pro výzkum věrnosti BUSCHMANN, Nikolaus - MURR, Karl Borromäus. „Treue“ als Forschungskonzept? Begriffliche und methodische Sondierungen. In BUSCHMANN, Nikolaus - MURR, Karl Borromäus (eds.) Treue. Politische Loyalität und militärische Gefolgschaft in der Moderne. Göttingen : Vandenhoeck \& Ruprecht, 2008, s. 11-35, zde s. 22 a násl.

36 Názor podle všeho zastává WOLVERTON, Lisa. Hastening toward Prague. Power and society in the medieval Czech lands. Philadelphia : Pennsylvania State University Press, 2001, s. 81.0 zdánlivém „paradoxu“ věrnosti a vazality, způsobeném tím, jak se zrcadlí v pramenech, pojednal inspirativně BLOCH, Marc. Feudální společnost. Praha : Argo, 2010, s. 243 a násl. 
politickou ideou, tak účinným právním regulativem. ${ }^{37}$ A to proto, že kodifikovala pružná a přitom závazná „pravidla hry“,38 kterými se řídila interakce mezi panovníkem a velmoži. ${ }^{39}$

Co do obřadu, v jehož rámci se přísahy doby knížecí odbývaly, nepanuje mezi historiky shoda. Přímočařejší úvahy Josefa Žemličky se snaží dokázat, že Kosmův oblíbený výraz sacramentum čerpal z odborné slovní zásoby středověké latiny, a protože byl odvozen od adjektiva sacer, nejenže odkazoval na něco posvátného a uctívaného, ale rovnou zahrnoval fyzickou přítomnost svatých relikvií, na něž se přísahalo. ${ }^{40}$ Opatrnější výklad Martina Nodla zase oponuje, že Kosmovo sacramentum je neutrální vyjádření, které sice evokuje přísahu, nemusí ale nutně znamenat, že by do ní byl zapojen světec a jeho tělesné pozůstatky. Nodl taktéž soudí, že se v přemyslovských Čechách tradovala nějaká prostší varianta rituálu a že přísaha na relikvie byla výjimkou. Když už ji zpravodajové čas od času uvádějí, nelitují námahy, aby ozřejmili bližší okolnosti. Nebude snad daleko od pravdy domněnka, že důvod pro zřídkavé uplatnění relikviáře v politické komunikaci tkví ve skutečnosti, že navazování věrnosti bylo samo o sobě považováno za posvátné. Nebylo třeba je dodatečně sakralizovat a spoléhat na synergický efekt, který měl zajistit církevní akt dotýkání se schránek na ostatky. ${ }^{41}$

Novým argumentem do diskuse by mohla být jednak komparace s křestanským Západem, kde byly relikviářové přísahy od 8. do 13. století převažujícím, nikoliv ale výlučným zjevem, ${ }^{42}$ jednak vlastní Kosmovo svědectví, pokud se mu naslouchá pečlivě. Že by ostatky svatých patřily k ceremoniální výbavě, bez níž by se domácí přísahy věrnosti neobešly, nelze doložit jinak, než s přispěním dvou kronikářských zápisů, jejichž slabinou je, že děj situují do zahraničního prostředí a že nesou punc mimořádnosti. Zaprvé: Jak víme, pražský děkan vypravuje o vpádu Čechů do Polska roku 1039, který byl úspěšně završen obsazením Hnězdna a vyhlášením Břetislavových dekret nad hrobem svatého Vojtěcha. Své odhodlání dodržovat nově vydané předpisy zpečetili prý bojovníci na čele s knížetem přísahou věrnosti. Učinili tak se zdviženými pravicemi a nad ostatky českého světce, avšak nedotkli se hrobu ani jeho obsahu, jak bývalo zvykem. ${ }^{43}$ Zadruhé: Kosmas

37 Zvláštnostem předmoderního práva, jehož překračování nemusí být nutně popřením jeho existence, se věnuje WEITZEL, Jürgen. Versuch über Normstrukturen und Rechtsbewußtsein im mittelalterlichen Okzident 450 - 1100. In LAMPE, Ernst-Joachim (ed.) Zur Entwicklung von Rechtsbewußtsein. Frankfurt am Main : Suhrkamp, 1997, s. 371-402; WEITZEL, Jürgen. „Relatives Recht“ und „unvollkommene Rechtsgeltung“ im westlichen Mittelalter. Versuch einer vergleichenden Synthese zum „mittelalterlichen Rechtsbegriff“. In CORDES, Albrecht - KANNOWSKI, Bernd (eds.) Rechtsbegriffe im Mittelalter. Frankfurt am Main : Lang, 2002, s. 43-62.

38 Koncept a slovník německého historika Gerda Althoffa adaptuje pro účely přemyslovské medievistiky KOPAL 2007.

39 Po Třeštíkovi DALEWSKI, Zbigniew. Rytuał i polityka opowieść Galla Anonima o konflikcie Bolesława Krzywoustego ze Zbigniewem. Warszawa: IH PAN, 2005, s. 221-222; KALHOUS, David. Anatomy of a duchy. The political and ecclesiastical structures of early Přemyslid Bohemia. Leiden : Brill, 2012, s. 19.

40 ŽEMLIČKA 2006.

41 NODL 2012.

42 KOLMER 1989, s. 233 a násl., 236-238; DAVID, Marcel. Le serment du sacre du IXe au XVe siècle 1. Strasbourg : Palais de l'Université, 1951, s. 89 a násl.

43 COSMAE, Lib. II, Cap. 4, s. 86. „Tunc dux extendens manum suam super sacram tumbam sic orsus est ad populi turbam: Extendite, fratres, simul vestras ad Dominum dextras et ad meos attendite sermones, quos volo ut vestre fidei sacramento confirmetis." Srv. NODL 2012, s. 437; KOLMER 1989, s. 236. 
informuje, že na dvorském sjezdu, konaném v Bamberku roku 1124 a obeslaném českým knížetem Vladislavem, se říšská nobilita zavázala přísahou na ostatky svatých, že vytáhne po boku Jindřicha V. do Saska proti povstalcům. ${ }^{44}$ Přestože Kronika Čechů žádné průkaznější stopy neposkytuje, nabízí alespoň ke zvážení hypotézu, že přísaha věrnosti nevyžadovala užití relikviáře a že se obvykle spokojila s řečí úst a těla. Počítat lze každopádně s pozdvižením pravice jakožto univerzálním, leč významově neurčitelným gestem, které se vyskytovalo napříč křest'anskou Evropou a které neuniklo Kosmově zvídavosti (extendite...dextras). ${ }^{45}$

Předpokládá se rovněž, že podobně jako se věrnost mezi „hráči“ na politické šachovnici přemyslovských Čech a Moravy (re)definovala skrze veřejně inscenovaný rituál slibů a př́ísah, museli mít zúčastnění aktéři po ruce instrumentárium symbolických úkonů, jimiž bylo možno věrnostní svazek platně ukončit. Přihlédnutí k elitní kultuře rozvíjející se v západním sousedství a k diplomatickým návštěvám Přemyslovců v říši by tomuto názoru mohlo dát opodstatnění. ${ }^{46}$ Potíž však je, že Kosmas vytvořil historickou fresku, která je poseta bílými místy a vyvolává otazníky. Jestliže se zaměříme na formální vyvázání se z povinnosti fidelity, za nejlépe zdokumentovanou lze označit kauzu vznešeného družiníka Zderada. Protože se jí budeme dále zaobírat, stačí zběžně předeslat, že Zderad byl oblíbencem krále Vratislava, jenž vládl 1061 - 1092 nejprve jako kníže Vratislav II., od roku 1086 jako král. Zderad, který byl Vratislavovi blízký, se nesnesl s nejstarším královským synem Břetislavem (II.), kterého urazil, pročež byl od Břetislavových ozbrojenců roku 1091 úkladně zavražděn. Důležité je, že mezi oběma trvala pouta věrnosti do okamžiku, než je Přemyslovec rozerval jednak slovem (abrenuncio ibi fidem meam $),{ }^{47}$ jednak výmluvným skutkem, když mrštil Zderadovi do obličeje svou rukavici (proiecit in faciem eius cirotecam). ${ }^{48}$ Méně okázalý způsob, jak vnést do soužití mezi „věrnými“ svár a současně upozornit, že se cosi nežádoucího přihodilo, bylo udržovat od druhých odstup. ${ }^{49}$ Nejinak si počínali moravští údělníci Oldřich a Litolt, potomci Konráda Brněnského, jež kronikář záměrně klade do opozice vůči „věrným“ synům olomoucké kněžny Eufemie, Svatoplukovi a Otovi.

44 COSMAE, Lib. III, Cap. 56, s. 229. ,..., spondeat nunc fidem super sacra plenaria, quod sua tollat arma et sequatur me post festum sancti Iacobi apostoli in Saxoniam.' Assenciunt omnes et collaudant principes atque coniurant bellum adversus Saxones secundum edictum cesaris."

450 pluralitě středověkých forem přísahy ve spojení s pozvednutím rukou vedle citované Kolmerovy monografie srv. BILLACOIS, François. Le corps jureur. Pour une phénoménologie historique des gestes du serment. In VERDIER, Raymond (ed.) Le Serment 1. Signes et fonctions. Paris : Editions du Centre national de la recherche scientifique, 1991, s. 93-101. Ze starších prací AMIRA 1909, s. 227 a násl., 257 a násl.; VON KÜNSSBERG, Eberhard. Schwurgebärde und Schwurfingerdeutung. Freiburg im Breisgau : Herder, 1941, s. 27-28. 46 WIHODA 2008, s. 78-79 s bibliografií.

47 Srv. COSMAE, Lib. III, Cap. 19, s. 184. „... Borivoy, cui iam abrenunciarat fidelitatem et fraternitatem suam et amiciciam."

48 COSMAE, Lib. II, Cap. 44, s. 150-151. K symbolice hozené rukavice ve smyslu zbavení se závazku SCHWINEKÖPER, Berent. Der Handschuh im Recht, Ämterwesen, Brauch und Volksglauben. 2. vyd. Sigmaringen : Thorbecke, 1981, zvl. s. 76, 82, 110; VON AMIRA - VON SCHWERIN 1943, s. 94. Odhazování předmětů na znamení ukončení závislosti vazala a pána rozebírá v souvislosti s rituálem zv. „exfestucatio“ BLOCH, Marc. Les formes de la rupture de l'hommage dans l'ancien droit féodal. In Nouvelle revue historique de droit français et étranger, 1912, roč. 36, s. 141-177, zde zvl. s. 154 a násl.

49 ALTHOFF, Gerd. Huld. Überlegungen zu einem Zentralbegriff der mittelalterlichen Herrschaftsordnung. In ALTHOFF, Gerd. Spielregeln der Politik im Mittelalter. Kommunikation in Frieden und Fehde (dále Spielregeln der Politik). Darmstadt: WBG, 1997, s. 199-228, zde s. 203 a násl.; ALTHOFF, Gerd. Ungeschriebene Gesetze. Wie funktioniert Herrschaft ohne schriftlich fixierte Normen. In Spielregeln der Politik, s. 282-304, zde s. 294 a násl. 
Není divu. Když kníže Břetislav II. vpadl roku 1099 na Moravu, aby sobě upevnil pozici a svému synovi Bořivojovi nástupnictví, olomoucká knížecí rodina setrvala a poddala se, kdežto Oldřich s Litoltem uprchli a své statky přepustili „na dálku“ Břetislavovi pouze proto, aby byly ušetřeny plenění. ${ }^{50}$

\section{(Ne)věrný kníže}

Dospěli jsme do bodu, kdy se můžeme posunout od právních rituálů k normativním představám, které se za vnějškovými projevy věrnosti ukrývají. ${ }^{1}$ Půdorys, na němž spočívala ve středověkých Čechách mocenská rovnováha knížete a předáků ,52 popisuje locus classicus Kosmova historického líčení a učebnicový př́íklad dobře známý z odborné literatury. Základní stavební kámen monarchie je pevně zabudován do Jaromírova „státnického“ proslovu, který zazněl roku 1034 u příležitosti nastolení knížete Břetislava I., následujícího na trůně po zesnulém otci Oldřichovi. Přemyslovský kníže Jaromír, slepý stařec těžce zkoušený dlouhodobým pobytem v žaláři, ustoupil tehdy od svých nástupnických nároků a usadil na pražský kamenný stolec mladšího a perspektivnějšího Břetislava. Během intronizační slavnosti Jaromír nechal Břetislava provolat za knížete a doporučil shromážděným Čechům, aby pro příště dbali „konsenzuálního“ modelu spolupráce mezi panovníkem a politickou reprezentací. ${ }^{53}$ Byl to ovšem kronikář Kosmas, kdo Jaromírovi „vnuknul“ svůj vladařský ideál a kdo si pro dosažení většího dramatického efektu vypomohl jednak biblickou látkou, jednak literární pozůstalostí po autorech z dob pohanského starověku ${ }^{54}$ :

„Po řádném dokonání obřadů pohřebních vzal [Jaromír] za ruku synovce Břetislava a vedl ho ke knížecímu stolci. A jako když se děje při volbě knížete, házeli přes mřiže hořejší síně peníze, deset tisíc nebo ještě více, mezi lid, aby se netlačili na knížete, sedícího na stolci, nýbrž raději chytali házené peníze. Když byl kníže posazen na stolci a nastalo ticho, Jaromír, který držel synovce za pravici, pravil k lidu: ,Hle, váš kníže!' A oni zvolali třikrát: ,Krlešu,' to je: Kirie eleison. A opět řekl Jaromír $k$ lidu: ,Přistupte z rodu Municů, přistupte z rodu Těpticů!' a volal jmenovitě ty, o nichž věděl, že jsou zvláště ve zbrani mocní, stáli ve věrnosti, udatní v boji a že vynikají bohatstvím. Když poznal, že u něho stojí, pravil: ,Poněvadž mi můj osud nedopouští, abych byl vaším knížetem, ustanovujeme vám tohoto a povyšujeme na knížete, abyste ho byli poslušni, jak je důstojno knížete, a povinnou věrnost mu zachovávali, jak náleží vládci. A tebe, synu, napomínám a opět a opět to v mysl ti vštěpovat budu, abys tyto zde ctil jako otce a miloval jako bratry a ve všech potřebách aby sis je bral

50 COSMAE, Lib. III, Cap. 9, s. 169-170. Srv. WIHODA, Martin. Morava v době knížecí 906 - 1197. Praha : NLN, 2010, s. 148 a násl.

51 Obecně DILCHER, Gerhard. Mittelalterliches Recht und Ritual in ihrer wechselseitigen Beziehung. In Frühmittelalterliche Studien, 2007, roč. 41, s. 297-316.

52 Výstižně TŘEŠTÍK 2011, s. 427.

53 Srv. BLÁHOVÁ 2002, s. 130 a násl.

540 jejich literární funkci KOLÁŘ, Antonín. Kosmovy vztahy k antice. In Sborník Filosofickej fakulty University Komenského, 1925, roč. 3, s. 21-99, zde s. 36 a násl. a nověji s korekturami ŠVANDA, Libor. K recepci antiky v Kosmově kronice. In Graeco-Latina Brunensia, 2009a, roč. 14, s. 331-340. 
za rádce. Těmto poruč hrady a lid ke správě, nebot’ na nich česká země stojí i stála a stát bude na věky." 55

Z četby Kosmovy kroniky se lze domýšlet, že interakce knížete a předáků, jak je zachycena v Jaromírově fingované promluvě, zahrnovala dvě kvalitativně svébytné vztahové roviny: věrnost a poslušnost. Až potud se historikové shodují. Méně jistoty ale panuje v otázce, jak obě roviny pojmově uchopit, už jen proto, že mezi nimi neexistovala žádná pevná a nepřekročitelná hranice. ${ }^{56} \mathrm{~S}$ odvoláním na klasika oboru Františka Grause přesto učiníme pokus, vychýlit pomyslné misky vah ve prospěch interpretace, která od sebe odlišuje jednostrannou, nekompromisní poslušnost (obedientia) a okolnostmi podmíněnou věrnost fungující na zásadě „něco za něco“ (fides, fidelitas). ${ }^{57}$ Kosmova dikce svádí přinejmenším k úvahám, že došlo-li k ozbrojenému střetu, byli Čechové podrobeni nastolenému Přemyslovci jakožto svému vojevůdci $(d u x)$ a rozkazy nejvyššího velitele museli plnit bez odmlouvání. 58

Jinak vypadala situace, pokud se knížata a jejich muži právě neúčastnili bojů. Vychází-li z Jaromírových úst respekt k síle velmožů a pobídka ke svornosti, lze $\mathrm{z}$ jeho dalších vět vyrozumět, že v klidovém období byla sounáležitost s elitou pěstována recipročně. ${ }^{59}$ Zůstával tudíž prostor k nejrůznějším kalkulacím s plněním věrnostních povinností, v zásadě však platilo, že členové politického národa

55 COSMAE, Lib. I, Cap. 42, s. 77-80. „Post expletis rite funebriis exequiis accipit Bracizlaum fratruelem et ducit eum ad sedem principalem; et sicut semper in electione ducis faciunt, per superioris aule cancellos decem milia nummorum aut plus per populum spargunt, ne ducem in solio comprimant, sed potius sparsos nummos rapiant. Mox duce locato in solio et facto silentio tenens dextram sui fratruelis Iaromir dixit ad populum: Ecce dux vester! At illi succlamant ter: Krlessu, quod est Kyrieleison. Et iterum Iaromir ad populum: Accedant, inquit, de gente Muncia! accedant de gente Tepca! et vocat eos nominatim, quos norat armis potentiores, fide meliores, milicia fortiores et divitiis eminentiores. Quos ut sensit adesse, dixit: Quoniam me mea fata non sinunt, ut sim vester dux, hunc assignamus vobis in ducem et collaudamus, quo ei obediatis, ut dignum est duci, et debitam fidelitatem exhibeatis, ut par est suo principi. Te autem, fili, moneo et repetens iterum iterumque monebo, istos colas ut patres, hos diligas ut fratres et in omnibus negociis tibi consiliarios habeas. His urbes et populum ad regendum committas, per hos enim Boemie regnum stat et stetit atque stabit in sempiternum." Překlad vybraných pasáží Kosmova kronika česká. 7. vyd. HRDINA, Karel - BLÂHOVÁ, Marie (eds.). Praha ; Litomyšl : Paseka, 2005, zde s. 75.

56 GRAUS, František. Herrschaft und Treue. Betrachtungen zur Lehre von der germanischen Kontinuität. In Historica, 1966, roč. 12, s. 5-44, zde s. 12-13.

57 GRAUS, František. Über die sogenannte germanische Treue. In GRAUS, František. Ausgewählte Aufsätze (1959 - 1989). Stuttgart : Thorbecke, 2002, s. 133-179, zde s. 176-177. O vztahu poslušnosti a věrnosti výběrově KERN, Fritz. Gottesgnadentum und Widerstandsrecht im früheren Mittelalter. Zur Entwicklungsgeschichte der Monarchie. 6. vyd. Darmstadt : WBG, 1973, s. 328 a násl., 359 a násl.; BOSL, Karl. Herrscher und Beherrschte im deutschen Reich des 10. - 12. Jahrhunderts. In BOSL, Karl. Frühformen der Gesellschaft im mittelalterlichen Europa. Ausgewählte Beiträge zu einer Strukturanalyse der mittelalterlichen Welt. München : Oldenburg, 1964, s. 135-155, zvl. s. 137 a násl., 154-155; GUREVIČ, Aron Jakovlevič. Kategorie středověké kultury. Praha : Mladá fronta, 1978, s. 143 a násl.

58 TŘEŠTíK 1968, s. 160-161. Jak si všiml Dušan Třeštík s příslovečným smyslem pro detail, specifické postavení panovníka ve válečném a klidovém stavu a s nimi spojená terminologická distinkce dux - princeps by mohly mít svůj předobraz v Isidorových Etymologiích. Srv. též TŘESŤíK 2004, s. 293-294; KOPAL 2010, s. 366.

59 Vedle Třeštíkových př́ispěvků uvedených výše srv. RUSSOCKI, Stanisław. Vznik vládního systému a způsob panování v patrimoniálních monarchiích střední Evropy. (Několik diskusních poznámek.). In Československý časopis historický, 1980, roč. 78, č. 3, s. 399-414, zde s. 407-408; RUSSOCKI, Stanisław. Le rôle de la „fidelitas“ et du „beneficium“ dans la formation des États slaves. In Acta Poloniae Historica, 1972, roč. 26, s. 171-188, zvl. s. 173, 179 a násl. Pro etnografické paralely MAIR, Lucy Philip. Primitive government. Harmondsworth : Penguin Books, 1970, s. 107 a násl., 166 a násl. K jejich aplikovatelnosti KELLER, Hagen. Reichsorganisation, Herrschaftsformen und Gesellschaftsstrukturen im Regnum Teutonicum. In Fondazione CISAM (ed.) Il secolo di ferro. Mito e realtà del secolo X 1. Spoleto : Presso la Sede del Centro, 1991, s. 159195, zde s. 189-191 a vozn. 
sdíleli hodnotu nazývanou v latinských pramenech "fides", nebo „fidelitas", jež byla obsahově mnohotvárná a nabývala ostřejších obrysů případ od případu. Kosmou častokrát skloňovaná kategorie, překládaná do moderního jazyka jako věrnost, svazovala ruce oběma stranám archaické „společenské smlouvy“, nejen vrchnímu správci přemyslovských držav (princeps), ale i vlivným osobnostem zdržujícím se okolo trůnu. Kníže měl těmto „lepším“ z lidu naslouchat, spolupodílet se s nimi na vládě a odměňovat je za jejich podporu ${ }^{60} \mathrm{Na}$ oplátku spoléhal, že vrstva složená z veřejně exponovaných církevních prelátů, bojovníků, úředníků a zástupců přemyslovského rodu bude svému knížeti zavázána oboustrannou loajalitou v míru a „slepou" oddaností ve válce. ${ }^{61}$

Někdy se soudí, že věrnostní pouta měla svůj původ v př́isaze skládané při intronizaci knížete a že dosednutí Břetislava I. na trůn roku 1034 je toho důkazem. ${ }^{62}$ Avšak Kosmas ani přísně vzato netvrdí, že Břetislavovi na počátku jeho vladařské kariéry někdo př́ísahal, ani blíže nepopisuje žádnou rituální inscenaci věrnosti, která by byla spojena s převzetím moci v režii Přemyslovců Břetislava a Jaromíra. Nezbývá proto, než pracovat s pouhými dohady a kombinacemi, pro něž by svědčily nanejvýš analogie $s$ inauguracemi panovníků v sousední ř́ŕši. ${ }^{63}$ Naopak je nade vši pochybnost, že vystupování, které se očekávalo od „věrných“ Čechů, bylo vzorem i pro moravské údělníky. Svatovítský děkan Kosmas si totiž neodpustil kratičkou poznámku, v níž se vyslovil s uznáním o příchylnosti (obedientia et fides), kterou k pražskému knížeti chovali pozůstalí po Otovi I. Olomouckém, kněžna Eufemie a děti Svatopluk s Otou (II.) Černým. ${ }^{64}$

Jde-li o křestanskou církví propagovanou etiku poslušnosti, ${ }^{65}$ nutno připomenout, že se ke stejné myšlenkové tradici hlásí Kosmas, když apeluje na čtenáře: Kdo chce dosáhnout spásy, musí být ochoten, zříci se vlastní vůle a odevzdat se autoritě jednak biblického zákona, jednak duchovních, kteří jsou prostředníky Boha a pozemskými

600 tom ŠVANDA, Libor. K obrazu ideálního panovníka v Kosmově kronice. In KRMíČKOVÁ, Helena et al. (eds.) Querite primum regnum Dei. Sborník príspěvkủ k poctě Jany Nechutové. Brno : Matice moravská, 2006, s. 211221, zde s. 219.

61 Strukturu této skupiny ilustruje záznam o sněmu v Dobeníně roku 1068. COSMAE, Lib. II, Cap. 23, s. 115, na nějž poukazuje IWAŃCZAK, Wojciech. Elita dworska w kronice Kosmasa. In DVOŘÁČKOVÁ-MALA, Dana (ed.) Dvory a rezidence ve středověku 3. Všední a sváteční život na středověkých dvorech. Praha : HÚ AV CR, 2009, s. 381-392, zde s. 385. Srv. ŽEMLIČKA, Josef. „Omnes Bohemi“. Od svatováclavské čeledi ke středověké šlechtě. In Mediaevalia Historica Bohemica, 1993, roč. 3, s. 111-133; WIHODA, Martin. Kníže a jeho věrní. Kosmas o světě předáků a urozených. In NODL, Martin - WIHODA, Martin (eds.) Šlechta, moc a reprezentace ve středověku. Praha : Filosofia, 2007, s. 11-29.

62 IWAŃCZAK 2009, s. 390; WIHODA 2008, s. 78. Autoři navazují na starší práce KULECKI, Michał. Ceremoniał intronizacyjny Przemyślidów w X - XIII wieku. In Przegląd Historyczny, 1984, roč. 75, č. 3, s. 441-451, zde s. 446, nebo opatrněji SCHMIDT, Roderich. Die Einsetzung der böhmischen Herzöge auf den Thron zu Prag. In BEUMANN, Helmut - SCHRÖDER, Werner (eds.) Aspekte der Nationenbildung im Mittelalter. Ergebnisse der Marburger Rundgespräche 1972 - 1975. Sigmaringen : Thorbecke, 1978, s. 439-463, zde s. 451.

63 Srv. SCHEYHING, Robert. Eide, Amtsgewalt und Bannleihe. Eine Untersuchung zur Bannleihe im hohen und späten Mittelalter. Köln : Böhlau 1960, s. 70 a násl.; SCHMIDT, Roderich. Königsumritt und Huldigung in ottonisch-salischer Zeit. 2. vyd. Sigmaringen : Thorbecke, 1981; SCHEIBELREITER, Georg. Der Regierungsantritt des römisch-deutschen Königs (1056 - 1138). In Mitteilungen des Instituts für Österreichische Geschichtsforschung, 1973 , roč. 81, s. 1-62.

64 COSMAE, Lib. III, Cap. 9, s. 170. „Ottonis autem filii Zuatopluk et Ottik cum matre sua Eufemia multum obedientes duci erant et fideles".

65 MELVILLE, Gert. Gehorsam und Ungehorsam als Verhaltensformen. In MELVILLE, Gert. Frommer Eifer und methodischer Betrieb. Beiträge zum mittelalterlichen Mönchtum. Wien ; Köln ; Weimar : Böhlau, 2014, s. 139159. Stručněji ANGENENDT, Arnold. Geschichte der Religiosität im Mittelalter. 3. vyd. Darmstadt : WBG, 2005, s 569-570. 
„bojovníky“ za jeho věc. ${ }^{66}$ Ve falzu zakládací listiny pražského biskupství, ${ }^{67}$ zakomponovaném do Kroniky Čechů, najdeme třeba zmínku o fundaci kláštera při kostele Sv. Jiřri v Praze. Osazen měl být jeptiškami, které by žily „pod řeholí svatého Benedikta a pod poslušenstvím abatyše Marie“. ${ }^{68}$ Jinde zase uvádí kronikář na scénu biskupa Vojtěcha s řezenským mnichem Kristiánem, synem Boleslava I. V rozmluvě předcházející Vojtěchovu odchodu z Čech se budoucí světec netají zklamáním, že se jeho christianizační záměry nesetkávají ve vlasti s pochopením. Nabízí proto svou biskupskou berlu Kristiánovi se slovy, že lid bude mít raději za pastýře Boleslavova potomka, že ho bude následovat a že člen vládnoucího rodu bude spíše schopen „trestati neposlušné“.69 Když později do majetkového sporu mezi hlavami přemyslovských diecézí, pražským Jaromírem-Gebhartem a olomouckým Janem, zasáhne kurie, obrací se papež Řehoř VII. přímo na knížete Vratislava II. V listu zaslaném do Čech žádá Vratislava, aby konfliktního Jaromíra, ztrpčujícího život jak knížeti, tak olomouckému biskupovi, „s úctou přijal a ve všem ho poslouchal jako svého duchovního otce a pastýře“70

Obedience byla ovšem vyžadována nejen církevní hierarchií na čele s papežem, ale i světskou vrchností. 0 podřízenosti bez kompromisů se Kosmas vyjadřuje jednak v citovaném Jaromírově proslovu, jednak v historce o dobrovolné abdikaci knížete Vladislava I., která ale vypovídá více o konkrétních rodinných vazbách Přemyslovců. Aniž bychom znali příčinu, proč ke změně na Pražském hradě došlo, víme alespoň tolik, že koncem roku 1117 povolal Vladislav z vyhnanství bratra Bořivoje II., svého předchůdce a konkurenta v boji o trůn, dobrovolně mu přepustil vládu a spokojil se s údělem v Čechách. Hlavní role na politickém jevišti se přesto Vladislav nevzdal. Kronikář, který byl Bořivojovi nakloněn, musel vysvětlit paradoxní zvrat, který nastal po roce 1117 v poměru knížete a údělníka. Kosmovi proto nezbylo, než se odvolat na Bořivojovu ušlechtilou povahu a pochválit, že se nenechal strhnout odstrašujícím příkladem uherských Arpádovců a že ukázal odstupujícímu Přemyslovci svou dobrou vůli: „Udělil svému bratru polovici svého knížectví, ležící od řeky Labe na sever, a byl též, ač mladšího, ve všem poslušen, a vždy ho ctí předcházeje, nic nečinil bez jeho rady." ${ }^{\text {"1 }}$

66 Poslední slova pražského biskupa Heřmana pronesená na smrtelném loži podle COSMAE, Lib. III, Cap. 49, s. 222. „Fateor enim, quia ego peccator compeccantes de peccato suo non redargui et potentes inique agentes et delinquentes non solum honoravi, verum etiam amavi, quos increpare et, si non obedirent, excommunicare debui. Postquam enim occubuit Bracizlaus iunior, quo nec fuit nec erit dux melior, hac in terra floruit iniquitas, germinavit superbia, pullulavit fraus, dolus et iniusticia, et ego semper dolens dolui, quod mihi cum bono duce non licuit mori. Ve mihi! quia silui, quia apostatricem gentem non revocavi nec in gladio anathematis pro Christo dimicavi: sed me ipsum et populum christianum passus sum per tactum manus cum gente non sancta pollui, sicut scriptum est: ,Qui tangit inmundum, inmundus erit' et: ,Qui tetigerit picem, inquinabitur ab ea' aut: ,Que conventio Christi ad Belial?' Apostatricem gentem dico Iudeos, qui per nostram negligentiam post baptismum relapsi sunt in Iudaismum. Unde valde timeo, ne Christus mihi hoc obiciat et inferiorem me proiciat in orcum". Srv. ERDMANN, Carl. Die Entstehung des Kreuzzugsgedankens. Stuttgart : Kohlhammer, 1935, s. 10-11, 185 a násl.

67 Codex diplomaticus et epistolarius regni Bohemiae 1 (805 - 1197). FRIEDRICH, Gustav (ed.). Pragae : Sumptibus Comitiorum regni Bohemiae, 1904 - 1907, č. 371, s. 342. Srv. TREŠTÍK 1968, s. 128-129.

68 COSMAE, Lib. I, Cap. 22, s. 43. „...sub regula sancti Benedicti et obedientia filie nostre, abbatisse Marie.“

69 COSMAE, Lib. I, Cap. 29, s. 52. „Te plebs ista mavult dominari et tibi magis obedire quam mihi. Tu consilio et auxilio tui fratris superbos comprimere, negligentes arguere, inobedientes corrigere, infideles increpare poteris."

70 COSMAE, Lib. II, Cap. 31, s. 127. „Adhuc etiam et hoc efficiente Mahtilda dominus papa legatis Boemorum tradit apices literarum, in quibus mandat et precipit duci, ut fratrem suum honorifice suscipiat et ei quasi patri suo et pastori per omnia obediat atque in pace cum Dei benedictione vivant."

71 COSMAE, Lib. III, Cap. 43, s. 218. „Borivoy autem non inmemor accepti beneficii dat fratri suo dimidiam sui ducatus partem, que sita ultra fluvium Labe tendit ad aquilonem, eratque fratri suo licet iuniori in omnibus obediens et semper honore eum preveniens nihil sine suo consilio gessit." 
Odsuneme-li stranou poslušnost, jíž lid ve zbrani prokazuje trůnícímu Přemyslovci, musí se v našem zorném poli objevit konečně také věrnostní svazek, tmelicí dohromady knížete a zemské předáky. Z Jaromírových rad Břetislavovi jsme poznali, že spolupráce $\mathrm{v}$ rámci politické elity měla $\mathrm{v}$ časech míru spočívat na radě a pomoci při správě knížectví. Co ale vskutku obnášela, dá se nejlépe ilustrovat na modelových postavách (ne)věrných panovníků a jejich služebníků, se kterými Kosmas seznamuje a kterými inspiruje své publikum. Není přitom bez zajímavosti, že na stránkách Kroniky Čechů vystupují hrdinové bok po boku antihrdinů. Jedni jsou vyzdvihováni, kdežto druzí, ač zatracováni, přeci svými odiózními činy napomáhají zvýraznit kontury samotné věrnosti. ${ }^{72}$ Snad nejproslulejšími „dábly“ vzbuzujícími opovržení jsou pak v kronikářově podání urození Vršovci, perfidní nepřátelé Přemyslovců (numquam fuere fideles), kteří se nerozpakují vztáhnout ruku na své pány a vládce, za což se jim dostává kruté, leč spravedlivé odplaty. Božím trestem, který na Vršovce dopadá, je nechvalně známé trojí vyvraždění rodu. ${ }^{73}$

O mnoho lépe si nestojí v Kosmových očích ani král Vratislav, vyportrétovaný v temných barvách s jasně patrnými rysy tyrana. ${ }^{74}$ Aniž by tak byl výslovně označen, je Vratislav hanlivě přirovnáván ke lstivé lišce a pomstychtivému medvědovi a obdařen charakteristickými atributy, které byly ve středověké učenecké diskusi kladeny do nesmiřitelného kontrastu s panovnickým ideálem. ${ }^{75}$ Jedním z dějových momentů, který celkově chmurný obraz prvního českého krále dokresluje, je příhoda z českého tažení do Míšeňska roku 1088. Vratislav tenkrát využil příležitosti, která se mu naskytla, aby vlákal do smrtelné léčky předáka Benedu. Jelikož Přemyslovce kdysi urazil, musel Beneda uprchnout ze země a nyní pobýval na biskupském dvoře v Míšni. Pod slibem bezpečí byl povolán k jednání na odlehlé místo za vojenským táborem, poté byl lstí odzbrojen a i když se pokusil hrdinně vzdorovat přesile, byl Vratislavovými bojovníky zavražděn a jeho mrtvola zneuctěna. Český král nedodržel dané slovo (sub fidei pacto), porušil tím pádem závazná „pravidla hry“ a podle dobových představ o reciprocitě v mezilidských vztazích se stal „nevěrným“76 Ba co víc, mezi současníky nechyběly hlasy přirovnávající Vratislava k antickému krutovládci Neronovi. Dokladem jsou nám sázavské přípisky ke Kosmově kronice, které sice vznikly až ve 2. polovině 12 . století, zřejmě však čerpaly ze starších nekrologických záznamů, prohlašujících Benedův tragický skon za mučednickou smrt. ${ }^{77}$

72 Srv. DEUTINGER 2006, s. 97.

73 COSMAE, Lib. I, Cap. 42, s. 79. K tomu KOPAL, Petr. Kosmovi dáblové. Vršovsko-přemyslovský antagonismus ve světle biblických a legendárních citátů, motivů a symbolů. In Mediaevalia Historica Bohemica, 2001, roč. 8, s. 7-40; WOLVERTON, Lisa. Cosmas of Prague. Narrative, classicism, politics. Washington : The Catholic University of America Press, 2015, s. 182 a násl.

74 REITINGER, Lukáš. Vratislav. První král Čechů. Praha : Argo, 2017, s. 53 a násl., jehož zasvěceného pramenného rozboru se přidržujeme.

75 Přehledně s literaturou ANTONÍN, Robert. Ideální panovník českého středověku. Kulturně-historická skica z dějin středověkého myšlení. Praha : NLN, 2013.

76 Boleslav Chrabrý, o němž píše Kosmas jako o Měškovi, si vysloužil nelichotivý titul perfidus za podobných okolností. Pozval do Krakova na hostinu Boleslava III., s nimž měl uzavřen mír, aby posléze nic netušícího Přemyslovce nechal oslepit a uvrhnout do žaláře, čímž měl porušit pax, fides a ius hospitale. COSMAE, Lib. I, Cap. 34, s. 61. Názory historiků na důvody, proč Kosmas zaměnil jména obou Piastovců, se různí. Viz LUŇ́́KOVÁ, Ludmila. Násilí mezi přemyslovskými knížaty. In Časopis Matice moravské, 2017, roč. 136, č. 2, s. 209-234, zde s. 212213,227 a v pozn.

77 COSMAE, Lib. II, Cap. 40, s. 143-145. Srv. REITINGER 2017, s. 62-63. 
Kritický podtón kronikářova vyprávění, který proniká míšeňskou epizodou Vratislavovy panovnické kariéry, vystoupí do popředí ještě zřetelněji, jestliže srovnáme tuto pasáž s pomstou královského syna a Kosmova oblíbence Břetislava II. na královském rádci a vilikovi Zderadovi. Zderad byl roku 1091 na Břetislavův pokyn úkladně zavražděn. Incident ne nepodobný zradě, které padl za obět’ Beneda, se odehrál na společné výpravě Vratislava a Břetislava proti Konrádovi Brněnskému. Hodnocení je však opačné. Zderad je prezentován nikoliv jako martyr, nýbrž jako zemský škůdce, poněvadž je činěn odpovědným za Vratislavovu vnitřní politiku tíhnoucí ke konfrontaci mezi pražskými a moravskými Přemyslovci. Nedbání příkazu věrnosti je najednou omlouváno snahou o obecné blaho. Viděno Kosmovou optikou, Břetislav se zasloužil o obnovu pořádku, když odstranil z cesty Zderada, všemocného Vratislavova důvěrníka, který byl překážkou pro smírné řešení konfliktu mezi členy vládnoucí dynastie. Odhlédneme-li od vznešených motivů sledujících vyšší zájem po nastolení míru, padá rovněž na váhu, že Zderad Přemyslovce veřejně zostudil. Ve sledované př́iběhové linii se zdá jen logické, že uražený Břetislav udělal symbolickou tečku za vztahem fidelity, visícím beztak na vlásku, když vilikovi vmetl do tváře svou rukavici se slovy „hle důvěru, kterou jsem ti slíbil, odvolávám“. Že nenáviděný králův rádce zanedlouho nato klesl pod kopími Břetislavových bojovníků, nebylo přičítáno k tíži jejich pánovi. ${ }^{78}$ Naopak. Na královském dvoře bylo násilné odklizení Zderada schvalováno jako oprávněné, třebaže se o činu nemluvilo nahlas. ${ }^{79}$

Dalším Přemyslovcem, jehož věrnost byla na stránkách Kroniky Čechů vystavena těžkým zkouškám z vladařské praxe, byl kníže Bořivoj II. Přestože mu Kosmas v porovnání s nástupcem Svatoplukem projevoval sympatie, sotva mohl omluvit Bořivojův sebezničující povahový sklon, dopřávat sluchu falešným našeptávačům a pod jejich vlivem opouštět v kritických okamžicích své spojence. Nečestně se Bořivoj II. zachoval, už když se nechal roku 1103 se svými rádci Hrabišou a Protivenem zkorumpovat polskými penězi. Zlákán prý vidinou tisíce hřiven, předčasně ukončil válečnou kampaň, jež pronikla přes Vratislavsko do Opavska s cílem zasáhnout do nástupnických bojů mezi Piastovci. Jakmile se Bořivoj domluvil se svým nepřítelem Boleslavem III. Křivoústým, bez výčitek opustil Boleslavova soupeře o polskou korunu Zbyhněva, čímž porušil dané slovo (fidem promissam abnuere). Ohledy ale nebral ani na moravského údělníka Svatopluka, kterého přiměl bojovat s Poláky a kterého těžce urazil (indignatus valde), protože se s ním nerozdělil o kořist. Pražský děkan Kosmas okomentoval tuto záležitost stroze a neubránil se moralizujícímu nadhledu: „'Ó mamone! Tys králem všeho zlého, přítelem podvodu, protivníkem a nepřítelem věrnosti, ty potlačuješ spravedlnost a podvracíš spravedlivé soudy."

78 COSMAE, Lib. II, Cap. 44, s. 150-151, citát na s. 150. „Quam, inquit, pollicitus sum, en abrenuncio tibi fidem meam, et avertens equum proiecit in faciem eius cirotecam." Pro interpretaci ANTONín 2013, s. 348-349.

79 COSMAE, Lib. II, Cap. 44, s. 151. „Solus rex meret et plorat et omnes iuvenem laudant, quamvis aperte laudare non audeant."

80 COSMAE, Lib. III, Cap. 16, s. 178-179, citát na s. 179. „O pecunia, tocius mali regina, fraudis amica, fidei hostis et inimica, tu iusticiam comprimis, recta iudicia subvertis!" O ambivalentním Kosmově vztahu k penězům jako nástroji středověké politiky KAMP, Hermann. Geld, Politik und Moral im hohen Mittelalter. In Frühmittelalterliche Studien, 2001, roč. 35, č. 1, s. 329-347, zde s. 334 a násl.; HECK, Roman. Problemy państwa i władzy w „Kronice“ Kosmasa, In Acta Universitatis Wratislaviensis. Historia, 1970, roč. 109, s. 5-19, zde s. 14-15. Obšírně WOLVERTON 2015, s. 176 a násl. 
Ztráceje postupně důvěru ve své okolí, v němž tušil všude nepřátele usilující o převrat, nechal se posléze Bořivoj roku 1107 obelstít agentem pracujícím ve prospěch údělníka Svatopluka, jakýmsi vnukem Hapatovým. Podle kronikáře šlo o člověka nebojácného a lstivého, který se po př́ijezdu z Moravy na knížecí dvůr neštítil, získat si důvěru tím, že odpřisáhl svou lživou povídačku o útěku před Svatoplukem a o připravovaném spiknutí proti Bořivojovi (ut sibi magis credatur, dicta sua confirmat sacramentis). Výstraha pohnula Bořivoje, aby potrestal za velezradu nevinné předáky Božeje s Mutinou (ut hostes rei publice punire), spřátelené Vršovce, byt' doposud setrvávali neochvějně při knížeti (amicos suos fideles). Že se stala křivda, uznává dokonce i Kosmas, který vršovskému rodu nebyl vůbec nakloněn. ${ }^{81}$ Plán na pomstu však ztroskotal, a protože zpřetrhal pouta loajality mezi knížetem a jeho „věrnými“, obrátil se vzápětí proti Bořivojovi. Božej s Mutinou byli včas varováni, prchli ode dvora a přešli do řad Bořivojových odpůrců, aniž by na nich ulpělo ódium zrádců. Hlavy vršovského rodu se nejprve sblížily s Přemyslovcem Vladislavem, který se již dříve odřekl „věrnosti, bratrství a přátelství ke staršímu bratru Bořivojovi (abrenunciarat fidelitatem et fraternitatem suam et amiciciam), načež roku 1107 Božej s Mutinou dopomohli k českému trůnu Svatoplukovi. ${ }^{82}$ Vypravěč pak nenechává nikoho na pochybách, že Bořivojův pád nebyl než přirozeným důsledkem jeho „přehmatů“, jichž se dopustil vůči svým nejbližším. Postup v příkrém rozporu se společenskou normou oslabil soudržnost mezi panovníkem a předáky, na jejichž „souhře“ vrchnostenská autorita stála a padala. Obrazně řečeno: „Neprozřetelně presekal silné větve, na nichž jednak sám oprén seděl, jednak jeho sláva visela, a skácel se z vysokého vrcholu. “83

\section{(Ne)věrný služebník}

Reciprocita mezi vládnoucími a ovládanými, kteří si prokazují navzájem věrnost slovy a skutky, vyžaduje, abychom ted' obrátili perspektivu zkoumání. Záhy ostatně zjistíme, že na přemyslovské panství se dá stejně dobře pohlížet shora jako zezdola, z pozice těch, kdo se nalézeli pod mocí pražského knížete. Archetypem proradného služebníka (deterior infidele), jehož Kosmas přivádí na scénu a jemuž propůjčuje hlavní úlohu v dramatu z bájného dávnověku, je nejmenovaný Durynk. Kronikář ho pohrdavě nazývá „druhým Jidášem“ (Iudas secundus), protože měl podle pověsti zavraždit knížecího syna, kterého mu svěřil do výchovy Vlastislav, vládce kmene Lučanů. Poté, co Čechové dobyli vítězství ve válce s Lučany, stalal Durynk chlapci hlavu

810 trestnému činu velezrady ve středověku HIS, Rudolf. Das Strafrecht des deutschen Mittelalters 2. Die einzelnen Verbrechen. Weimar : Böhlau, 1935, s. 36 a násl. Kontroverze dosud trvá ohledně rozlišení zločinu proti majestátu a infidelity, což dokumentují ESDERS, Stefan. Treueidleistung und Rechtsveränderung im frühen Mittelalter. In ESDERS, Stefan - REINLE, Christine (eds.) Rechtsveränderung im politischen und sozialen Kontext mittelalterlicher Rechtsvielfalt. Münster : Lit, 2005, s. 25-61, zde s. 32 a násl.; WEITZEL, Jürgen. Das Majestätsverbrechen zwischen römischer Spätantike und fränkischem Mittelalter. In WEITZEL, Jürgen (ed.) Hoheitliches Strafen in der Spätantike und im frühen Mittelalter. Köln : Böhlau, 2002, s. 47-83; HAGENEDER, Othmar. Das crimen maiestatis, der Prozeß gegen die Attentäter Papst Leos. III. und die Kaiserkrönung Karls des Großen. In MORDEK, Hubert - KEMPF, Friedrich (eds.) Aus Kirche und Reich. Studien zu Theologie, Politik und Recht im Mittelalter. Festschrift für Friedrich Kempf zu seinem 75. Geburtstag und fünfzigjährigen Doktorjubiläum. Sigmaringen : Thorbecke, 1983, s. 55-79, zvl. s. 64 a násl. V Kosmově vnímání ale zjevně oba pojmy splývaly, jak potvrzuje níže rozebíraná kauza údělníka Litolta. COSMAE, Lib. III, Cap. 12, s. 172.

82 COSMAE, Lib. III, Cap. 19, s. 184-185.

83 COSMAE, Lib. III, Cap. 9, s. 184. „Talibus artibus atque insidiis vir bonus et simplex dux Borivoy deceptus et multum mendaciis credulus ramos robustos, quibus et ipse innixus sedit et honor suus pependit, incaute precidit et ab alto culmine cecidit." 
sekerou a odnesl ji na podnose českému knížeti Neklanovi v očekávání, že bude odměněn. Panovníka zastihl v jeho sídle na pražském hradě, se svým ohavným „darem“ byl nicméně odmrštěn. Za všeobecného opovržení byl nakonec Durynk postaven před výběr, jakým způsobem chce ukončit svůj život. ${ }^{84}$ "Já jsem směl zabíti svého nepř́tele, ale ty nikoliv svého pána," odvětil Neklan krutému vychovateli. Vyjádřil tak hluboce zakořeněné přesvědčení, jemuž přikyvuje Kosmas, že vztáhnout ruku na svého pána znamená dopustit se současně těžkého hříchu proti božímu přikázání (peccatum) a závažného zločinu proti pozemskému zákonu (scelus crudele). ${ }^{85}$ Zrádné jednání tu kronikáře přímo vybízí ke srovnání s novozákonní předlohou, jestliže Durynk, podoben Jidáši, žádá od panovníka honorář za smrt Vlastislavova nedospělého synka. ${ }^{86}$

V seznamu Kosmových záporných hrdinů bychom mimoto našli jméno znojemského knížete Litolta. Po vyhnání z Moravy knížetem Břetislavem II., jehož pozadí nám zůstává utajeno, našel Litolt útočiště ve službách Gotfrida, hraběte na hradě Raabs. Jelikož se těšil Gotfridově „přátelské důvěre“, byla mu tato rakouská pevnost svěřena do správy (sub fide amicabiliter prestitum). Přemyslovský exulant si ale z Raabsu udělal základnu pro přepadání vesnic na moravské straně hranice, čímž vyprovokoval Břetislava k ozbrojené odvetě. Pod tíhou událostí, když hrozilo, že se Gotfried s Břetislavem za jeho zády dohodnou, odhodlal se znojemský Přemyslovec k akci a lstí se zmocnil Raabsu, jehož posádku vylákal z hradeb. Gotfried se cítil zrazen a svého někdejšího chráněnce obětoval. $V$ souladu s právním obyčejem provolal Litolta zrádcem (perfidum esse) a nepř́telem země (rei publice inimicum) ${ }^{87}$. Aby o sídelní pevnost nepřišel, musel ovšem spojit síly s Břetislavem. Litolt udatně vzdoroval, tenčily se mu však zásoby, a tak mu po několika týdnech obléhání nezbylo, než se pod rouškou noci spasit útěkem. ${ }^{88}$

Jiný exemplární případ, na němž je demonstrováno, kterak strážce pevnosti zrazující důvěru svého velitele dochází spravedlivého potrestání, nabízí osobnost vznešeného Přivitana. Kosmovo líčení ho zastihuje roku 1109 na Pražském hradě. Ve víru nástupnických sporů mezi Přemyslovci se Přivitan zasadil, aby sídlo českých knížat přešlo do rukou Bořivoje II. Jakmile se však roku 1110 na trůně usadil Vladislav I., byl Bořivojův straník za svou oddanost „odměněn“ jednak vypovězením do Polska, jednak potupným, veřejně vykonaným trestem nošení prašivého psa na zádech. Rituální praktika měla zbavit provinilého šlechtice jeho cti (talem honorem portat), přičemž se u její sociální funkce dá postihnout vývojový posun od prostř̌edku smíření v 10. století k ryze sankčnímu opatření ve 12 . století. Pachatel, který pochod hanby podstoupil, byl podle Jakoba Grimma symbolicky degradován na úroveň zvířete a jako zviŕre mohl být prostě zabit a pověšen. Bernd Schwenk ve psu spatřuje narážku na

84 COSMAE, Lib. I, Cap. 13, s. 29-32. Srv. GRAUS 1962, s. 151-152.

85 Obecně HELBIG 1951, s. 290.

86 COSMAE, Lib. I, Cap. 13, s. 31-32, citát na s. 31. „Aufer ab aspectu nostro tua dona, sceleste, tua scelera excedunt modum et veniam nec dignam inveniunt vindictam. Ad hoc flagicium nec potest dignum excogitari preiudicium nec par supplicium. An putas, quod facere non potuissem, quod fecisti, si voluissem? Mihi autem fuit licitum occidere inimicum, sed non tibi dominum. Hoc quod peccasti peccatum maius est, quam dici potest peccatum." Srv. TŘEŠTÍK, Dušan. Miscellanea k I. staroslovanské legendě o sv. Václavu: „Každý kdo povstává proti pánu svému, podoben jest Jidáši“. In Československý časopis historický, 1967, roč. 15, č. 3, s. 337-343, který rozvíjí podněty GRAUS 2002, s. 144, 152, 174-175; GRAUS 1966, s. 30-31.

87 HIS, Rudolf. Das Strafrecht des deutschen Mittelalters 1. Die verbrechen und ihre Folgen im allgemeinen. Leipzig : Theodor Weicher, 1920, s. 581-582.

88 COSMAE, Lib. III, Cap. 12, s. 172. O Litoltovi WIHODA 2010, s. 150-152. 
věrnost, nejinak Stefan Weinfurter, který navíc připomíná biblický kontext, v němž tento čtyřnohý tvor evokuje nečistotou a zkaženost. Zdrženlivější Jean-Marie Moeglin zase míní, že zakomponování psa coby běžné součásti dvorského koloritu není ničím více, než výrazem privilegovaného statusu trestance, a tedy signálem, který byl pro obecenstvo bez obtíží srozumitelným. ${ }^{89}$

Bud' jak bud', stojí za povšimnutí, že akt pomsty vykonaný na Přivitanovi ospravedlňuje Kronika Čechů právě obviněním z účasti na vzpouře a z porušení věrnostních slibů Vladislavovi (Wladizlao duci promissam fidem derogat). Kronikářovo podání, ač tendenční, ${ }^{90}$ věrohodně dokumentuje, že zpronevěřilost vůči knížeti nebyla brána na lehko, že naopak uváděla do pohybu soukolí trestního procesu. Vyvstává zároveň otázka, co dělat, když bojovník uvízne v konfliktu loajalit mezi panovníkem současným a minulým, který byl sehnán z trůnu. ${ }^{91}$ Kosmas moralizuje, aniž by prozrazoval, jak by se podle jeho názoru dalo překonat dilema, kdy věrnost jednomu Přemyslovci zkrátka musela mít za následek „nevěrnost“ jinému, úspěšnějšímu kandidátu na pražský stolec. ${ }^{92}$

V průběhu válek „více než občanských“ (bellum plus quam civile) ${ }^{93}$, zuřících mezi českými a moravskými Přemyslovci, mohlo porušení fidelity spočívat konečně i v tom, že bojovník opustil svévolně bezpečí hradu svěřeného k hájení a přeběhnul do opozičního tábora. Hromadná dezerce byla reálnou hrozbou, v jejíž uskutečnění doufal Svatopluk Olomoucký, když se roku 1105 vypravil k sídelnímu hradu, aby svrhl Bořivoje II. z trůnu. Protože se mu ale nepodařilo ovládnout Prahu lstí, obrátil se bez boje na spěšný ústup na Moravu. Obezřetný kníže Bořivoj, jenž si nedělal o svých ozbrojencích iluze (timuit suorum perfidiam, ne sua castra deserentes ad hostium se transferant miliciam), prý tenkrát ani nepomýšlel pronásledovat vojsko svého poraženého soka dál, než k pomeznímu hvozdu. ${ }^{94}$ Není divu. Později byl Svatoplukem opravdu svržen, avšak když se mu po smrti olomouckého údělníka naskytla roku 1109 př́ležitost, neváhal a sám využil skrytých sympatizantů v řadách hradské posádky (perfidorum), aby znovu opanoval centrum knížecích Čech a Moravy. ${ }^{95}$

Na opačném pólu hodnotového spektra, než kde se nacházejí spiklenci proti panovníkovi, ocitají se v Kosmově historickém opusu „věrní“ služebníci, na jejichž podpoře

89 Klasicky GRIMM, Jacob. Deutsche Rechtsaltertümer 2. Darmstadt : WBG, 1974, s. 254 a násl. S korekcemi SCHWENK, Bernd. Das Hundetragen. Ein Rechtsbrauch im Mittelalter. In Historisches Jahrbuch, 1990, roč. 110, s. 289-308 (o Přivitanovi na s. 299); WEINFURTER, Stefan. Ein räudiger Hund auf den Schultern. Das Ritual des Hundetragens im Mittelalter. In AMBOS, Claus et al. (eds.) Die Welt der Rituale. Von der Antike bis heute. Darmstadt: WBG, 2005, s. 213-219 (o Přivitanovi na s. 215-216); MOEGLIN, Jean-Marie. Harmiscara - harmschar - hachée. Le dossier des rituels d'humiliation et de soumission au Moyen Âge. In Archivum latinitatis medii aevi, 1996, roč. 54, s. 11-65 (o Přivitanovi na s. 40 v pozn. a na s. 44).

90 Srv. ANTONÍN 2013, s. 310.

910 tom MÜLLER, Jan-Dirk. Spielregeln für den Untergang. Die Welt des Nibelungenliedes. Tübingen : Niemeyer, 1998, s. 159 a násl.; ALTHOFF, Gerd. Verwandte, Freunde und Getreue. Zum politischen Stellenwert der Gruppenbindung im früheren Mittelalter. Darmstadt: WBG, 1990, s. 7-9; VAN EICKELS, Klaus. Verwandtschaft, Freundschaft und Vasallität. Der Wandel von Konzepten personaler Bindung im 12. Jahrhundert. In DENDORFER, Jürgen - DEUTINGER, Roman (eds.) Das Lehnswesen im Hochmittelalter. Forschungskonstrukte - Quellenbefunde - Deutungsrelevanz. Ostfildern : Thorbecke, 2010, s. 401-412, zde s. 407-409. Pro mladší dobu a "lenní" věrnost SPIESS, Karl-Heinz. Loyalität und Illoyalität an spätmittelalterlichen Fürstenhöfen im Reich. In Loyalty in the Middle Ages, s. 183-204.

92 COSMAE, Lib. III, Cap. 32, s. 202-203.

93 COSMAE, Lib. II, Cap. 45, s. 151; Lib. II, Cap. 47, s. 154. Srv. WOLVERTON 2015, s. 197 a násl.

94 COSMAE, Lib. III, Cap. 17, s. 181-182.

95 COSMAE, Lib. III, Cap. 28, s. 198. 
„Česká země stojí i stála a stát bude na věky." ${ }^{96}$ Ne náhodou jsou mužové pohybující se v blízkosti knížete označováni jako fideles ducis. Protože se těší důvěře Přemyslovců a vládnoucímu rodu se odvděčují skutky, jsou jim svěřovány nejnaléhavější úkoly vyplývající z potřeb středověké vládní praxe. ${ }^{97}$ Pro ilustraci není třeba chodit daleko: Když Boleslav I. hledal někoho, kdo by tajně převezl tělo zavražděného bratra Václava do kostela Sv. Víta, údajně proto, aby Václavova zázračná moc byla připisována Vítovi, obrátil se Kosmou démonizovaný „bratrovrah“98 na své věrné družiníky (fidis clientibus). ${ }^{99}$ Zrovna tak mohl vsadit na své domácí přívržence kníže Oldřich, který se roku 1004 vrátil z ř́ššsého zajetí do vlasti, načež pověřil jednoho „sobě věrného bojovníka“ (militem mittit sibi fidelem), aby tajně pronikl do Prahy obsazené v té době Boleslavem Chrabrým a aby pomohl zevnitř při osvobozování sídelní pevnosti od Poláků. ${ }^{100}$

Na přízni vládnoucích Přemyslovců byli v Kosmově době závislí rovněž pražští biskupové, od kterých se požadovalo fidele servicium. ${ }^{101}$ Dva z vrcholných církevních prelátů zmiňovaných v Kronice Čechů přitom jdou př́ikladem a ztělesňují kánon vlastností, jimiž se měl vyznačovat přemyslovský služebník v sutaně. Prvním je litoměřický probošt Lanc, důvěrník Vratislava II., jehož chtěl kníže prosadit za biskupa na kolokviu v Dobeníně roku 1068. Vratislav musel od svého záměru upustit poté, co narazil na nesouhlas zemských předáků, kteří by na biskupském stolci raději viděli Přemyslovce Jaromíra. Kosmova barvitá historka o volebním shromáždění Čechů, jež se postavilo knížeti na odpor, stojí přesto za zaznamenání. Skýtá totiž vítané pramenné svědectví o dobovém významu fidelity.

V úryvku typickém pro literární žánr zv. laudatio ${ }^{102}$ se o hlavním protagonistovi dobenínských jednání dočítáme slova chvály, v nichž Kosmas velebí nejen Lancův rodokmen, učenost, vážnost a mravy, ale především jeho příchylnost k přemyslovskému trůnu: „Toho času žil na dvoře knížecím jakýsi kaplan Lanc, ze Saska ze vznešeného rodu pocházející, muž vysoce důstojný a velmi učený, povýšený na probošta kostela litoměrického, mravy i životem ne v rozporu s hodností biskupskou. A poněvadž zůstával knížeti vždy věrný, kníže všemožně o to stál, aby byl biskup pražský." Obdivným tónem pak hovoří Vratislav k zástupům bojovníků: „Výborná tvá věrnost, každého dne mně osvědčovaná, vyžaduje toho a nutí mě, abych učinil, co chci dnes učiniti, a aby se z toho poučili budoucí, jak mají býti svým pánům věrni." ${ }^{103}$

96 COSMAE, Lib. I, Cap. 42, s. 79. „...per hos enim Boemie regnum stat et stetit atque stabit in sempiternum.“

97 Srv. DEUTINGER 2006, s. 106.

98 TŘEŠTÍK 1968, s. 163; ANTONÍN 2013, s. 178-179.

99 COSMAE, Lib. I, Cap. 19, s. 38.

100 COSMAE, Lib. I, Cap. 36, s. 64-65.

101 Viz chválu Šebíře COSMAE, Lib. I, Cap. 41, s. 76-77. „Severus presul successit in ordine sextus, qui tempore iuventutis mire enituit decore agilitatis, quia, quotquot erant in curia ducis, omnes suis precellens obsequiis, sedulum suo domino et magis gratum, quia fidele, exhibebat servicium."

102 Přehledně ŠVANDA, Libor. Chvály osob v Kosmově kronice. In Sborník prací Filozofické fakulty brněnské univerzity. Řada klasická N. Graeco-Latina Brunensia, 2005, roč. 10, s. 85-111, zde s. 89 a násl.

103 COSMAE, Lib. II, Cap. 22-24, s. 113-117, citáty na s. 114 a 115. „Erat autem tunc temporis in curia ducis quidam Lanczo capellanus, de Saxonia nobili prosapia natus, vir personatus et admodum literatus ac prepositura Lutomericensis ecclesie sublimatus, moribus et vita non contradicens honori pontificatus; et quia duci semper fidelis mansit, omnibus modis dux elaborabat, his Pragensis presul ut sit. ...,Egregia tua fides mihi spectata cotidie exigit hoc et cogit me, ut faciam, quod facturus sum hodie, et ut per hoc discant posteri, quantum dominis suis debeant fideles fieri." Srv. ŠVANDA, Libor. Chvály osob v česko-latinských historiografických textech 12. století. Disertační práce na Ústavu klasických studií FF MU v Brně. Brno, 2009b, s. 120. K interpretaci Vratislavova počínání v návaznosti na snahy o zř́izení arcibiskupství REITINGER 2017, s. 219 a násl. 
S větším zdarem proběhla biskupská volba, která roku 1099 vynesla do čela pražské diecéze Heřmana, kaplana blízkého knížeti Břetislavovi II. V dialogu, v němž se na Břetislava obrací jeho spojenec a švagr Wiprecht z Grojče, aby doporučil ustanovení Heřmana za biskupa, je obsažena sice mnohomluvná, pro naše téma nicméně důležitá chvalořeč: „Kdysi, dokud žil král, tvůj otec, má rada něco platívala; nyní žijí na světě lidé takových mravư, že sebe sami za něco mají, ač nic nejsou, a nelíbí se jim nic, co jiný radí, nýbrž jen to, co si myslí sami. Ale vy lépe víte, že v tak svaté věci ti, kdo radí ku prospěchu církve svaté, mají býti prosti hněvu a nenávisti, prosti útrpnosti a prátelství. Nebot' kde ty věci duchu vadí, klame se lidský úsudek. Mne však ani přátelství s nikým nezavazuje, ani útrpnost nemate; ani mne nenávist neštve, ani hněv nerozněcuje, abych nevyslovil před vámi, čeho žádá řád spravedlnosti. Jest tu kaplan otce tvého a nyní tvůj, jménem Heřman, jejž vy lépe znáte než já. Býval vždy v službě královské stálý, v tajemství věrný, v poselstvích spolehlivý jednatel, cudný, střízlivý, pokorný a skromný, žádný násilník, žádný ctižádostivec, žádný hrdopýšek, a co je první ctností u duchovního, obzvláště učený; pokud lze hleděti k lidskému mínění, jeví se mužem dobrým a bezvadným; jen jediné mu snad vadí, že jest cizinec“. 104

Kronikář užívá rétorické figury známé jako notatio, když obdařuje svého hrdinu dlouhým řetězcem přívlastků, v Heřmanově případě veskrze kladných, odmyslíme-li si kritickou narážku na cizí původ. Přes veškerou rozvláčnost Kosmova uměleckého projevu ale bedlivému oku neunikne, že se chvála nevyčerpává diskrétností, diplomatickým taktem, nebo obvyklými ctnostmi duchovního, jež korunuje učenost. Jako už tolikrát předtím, i při biskupské volbě roku 1099 byla skloňována oddanost vládnoucím Přemyslovcům coby klíčová charakteristika středověkých Čechů (fidelis, fidus).

\section{Věrnost v Kosmově kronice}

V závěrečné rekapitulaci bude vhodné, shrnout poznatky, ke kterým dospělo zamyšlení nad Kronikou Čechů sepsanou ve 12. století od pražského děkana Kosmy. V návaznosti na průkopnickou monografii Dušana Třeštíka jsem se tázal, jakým způsobem pracuje kronikář s kategorií věrnosti neboli fidelity, jež se stává pro moderní historiografii výzvou a pro humanitně orientované badatele čím dál přitažlivějším sociokulturním jevem. Oproti dřívějšku jsou její morální, politické a právní aspekty studovány nezávisle na tradičních dogmatech o „germánském“, nebo „feudálním“ středověku. Věrnost je tak více než kdy předtím vnímána jako faktor měnící se v prostoru a čase, hlavně je ale považována za základní pilíř společnosti v jejím dějinném vývoji, nebot' se soudí, že usnadňuje soužití mezi lidmi a přispívá k jeho stabilitě.

\footnotetext{
104 COSMAE, Lib. III, Cap. 7, s. 167-168. ,...,dum rex pater tuus viguit, meum consilium valuit; nunc horum vivunt homines morum, qui semetipsos putant aliquid esse, cum nihil sint, et quibus nullius nisi quod ipsi sapiunt placet consilium. Sed vos melius scitis, quod in tam sancto negocio, qui consulunt sancte ecclesie utilitati, vacuos decet esse ab ira et odio, a misericordia et amicitia, nam ubi ista officiunt animo, humana fallitur opinio; me autem nec alicuius amicicia obligat, nec misericordia supplantat, nec odium exagitat, nec ira inflammat, quo minus coram vobis eloquar, iusticie quod postulat ordo. Est patris tui et nunc tuus capellanus, quem vos melius nostis, nomine Hermannus. Hic semper fuit regis in servicio constans, in commisso fidelis, in legationibus agendis fidus executor, castus, sobrius, humilis et modestus, non violentus, non ambitiosus, non elatus et, que prima est in clerico virtus, adprime litteratus et, quantum spectat ad humanam opinionem, cernitur esse bonus vir et perfectus ad unguem, si solum non obsit, quod hospes sit." Srv. ŠVANDA 2009b, s. 116-117; TŘEŠTÍK 1968, s. 147; KOLÁR 1925, s. 55-57.
} 
Osu výkladu o fidelitě tvoří „politická hra“ mezi knížaty z rodu Přemyslovců a zemskou elitou, což je dáno prostou skutečností, že právě o nich Kosmas zanechal nejvíce hmatatelných stop. Abych hlouběji pronikl k „ideologii věrnosti“ (Dušan Třeštík) a odhalil její místo v životě knížecích Čech a Moravy, vypomohl jsem si jazykovým a praxeologickým rozborem Kroniky Čechů. Šlo mi zaprvé o zmapování výskytu u termínů fides a fidelitas, které v jazyce středověkých pramenů odpovídají našemu pojmu věrnosti. Zadruhé bylo cílem zachytit v konkrétních situacích panovníky a jejich služebníky, jež jsou prohlašováni za (ne)věrné a jež se v Kosmově světě zhostili role bud' hrdinů vybízejících k následování, nebo padouchů hodných odsouzení. Metodologickou inspiraci jsem tady čerpal z historické dílny Františka Grause a pod jeho vlivem odlišil jednostrannou, nekompromisní poslušnost vyžadovanou za válečného stavu (obedientia). V protikladu k ní je traktována věrnost, podmíněná okolnostmi a pěstovaná v době míru na zásadě reciprocity (fides, fidelitas), jíž jsem se věnoval podrobněji.

Do zorného pole se dostaly nejprve rituály věrnosti, které vyznačovaly počátek a konec věrnostních svazků, eventuelně utvrzovaly již existující, oboustranně platné závazky mezi vládcem a ovládanými. Při četbě Kosmovy kroniky lze narazit v první řadě na sliby a přísahy, které se připomínají v souvislosti s uzavíráním mírových smluv a vojenských spojenectví se sousedními monarchiemi stejně jako v krizových a politicky vypjatých okamžicích. Tehdy, kdy si Přemyslovec na trůně chtěl „pojistit“ své muže a kdy měl na zřeteli obranyschopnost hradské soustavy, řešení nástupnického rébusu, obsazení biskupského stolce, nebo dodržování zákonů. Přestože nechybějí doklady o křivopřísežnicví, Kosmovy příběhy z našich starších dějin vzbuzují i tak přesvědčení, že věrnostním slibům a přísahám se věřilo a že Přemyslovci spoléhali na jejich mobilizační, integrační a garanční funkci. Že porušení fidelity nebylo ani zdaleka bráno na lehkou váhu, je zřejmé z exemplárního potrestání jistého Přivitana, který byl odsouzen k nošení prašivého psa na zádech a vypovězen do Polska, protože se zpronevěřil knížeti Vladislavovi I.

Co bylo vlastně obsahem věrnosti spojující Přemyslovce s vlivnými osobami v jejich bezprostředním okolí? Odpověd’ se zdá být ukryta ve „státnické“ řeči knížete Jaromíra, kterou měl pronést, když urovnával cestu k trůnu pro mladšího Břetislava I. Jaromírovými ústy Kosmas propaguje vzájemně prospěšnou spolupráci při správě knížectví, která je vystavěna na půdoryse fidelity. Všeobecně byli členové politické elity vyzváni, aby ve válce zachovávali bezmeznou podřízenost a nastal-li klid zbraní, tedy alespoň solidaritu podle hesla „něco za něco“. Panovníkovi bylo zase kladeno na srdce, aby velmožům naslouchal, svěřoval jim úřady a odměňoval je za jejich ochotu podílet se na chodu země. Jak konkrétně měla ovšem jejich „spoluvláda“ v dobách míru vypadat, ilustruje svatovítský kronikář na příkladech. Dozvídáme se, že fidelita zahrnovala povinnosti negativního i pozitivního rázu. Na jednu stranu se předpokládalo, že si „věrní“ mezi sebou nebudou jakkoliv škodit, takže bylo zapovězeno, aby se znevažovali (Zderad, Beneda), prohřešovali se proti slibu věrnosti (Přivitan), byli nespravedlivě vystaveni trestnímu stíhání za zradu (Božej, Mutina), uchylovali se bez závažného důvodu k vojenské lsti (Litolt), porušovali dané slovo, nebo se rovnou připravovali o život (Vratislav). Strážci pevností a velitelé nesměli svévolně dezertovat, 
nebo přeběhnout k nepř́teli (Přivitan), natož aby se nechávali zkorumpovat penězi (Bořivoj II., Hrabiša, Protiven). Avšak nejhorším zločinem, vyvolávajícím opovržení, bylo vztáhnout ruku na svého pána (Vršovci, bájný Durynk).

Na druhou stranu Kosmas neopomíjí zdůraznit u věrnosti její pozitivní složku, jejímž působením jsou knížecí důvěrníci (fideles ducis) „manévrováni“ do plnění úkolů, které pro obtížnost a naléhavost nelze svěřit nikomu jinému. Boleslav I. na ně prý spoléhal, když chtěl zahladit památku na zavražděného bratra Václava. Oldřichovi byli oporou, když osvobozoval Prahu od Poláků. Nejinak se hledělo na vrcholné představitele české a moravské církve, přinejmenším o pražských biskupech víme, že byli knížeti povinováni loajální službou (fidele servicium). Specifikována je její náplň u Heřmana, kaplana přemyslovského knížete Břetislava II. a kandidáta na biskupský úřad, u něhož si Břetislav cenil oddanosti, diplomatického nadání a schopnosti uchovat tajemství. Nakonec se nelze ubránit skepsi ohledně lenního paradigmatu, kterého se po Grausově vzoru chopil Třeštík. V Kronice Čechů postrádáme sebenepatrnější údaje, naznačující, že by světští, nebo duchovní činitelé přejímali na svá bedra spolu se závazkem věrnosti nějaká knížecí práva, úřady či statky ve formě léna. Nelze tím pádem dovozovat, že by se u nás vyvinul klasický lenní systém porovnatelný se západní Evropou. Na vratké půdě se pohybují ale i ti, kdo tvrdí, že zdroj fidelity tkvěl v kolektivních slibech či přísahách, skládaných novému knížeti během nastolovacího ceremoniálu (Břetislav I.), poněvadž Kosmovy zápisy nemohou jejich tezi jednoznačně ani potvrdit, ani vyvrátit.

Cituj:

RAZIM, Jakub. Věrnost v Kosmově kronice. In Forum Historiae, 2019, roč. 13, č. 2, s. 18-39. ISSN 1337-6861. DOI: https://doi.org/10.31577/forhist.2019.13.2.2

PhDr. Mgr. Jakub Razim, PhD et PhD

Právnická fakulta Masarykovy univerzity

Veveři $158 / 70$

61180 Brno

Česká republika

Právnická fakulta Univerzity Palackého

17. listopadu 8

77111 Olomouc

Česká republika

jakub.razim@post.cz 